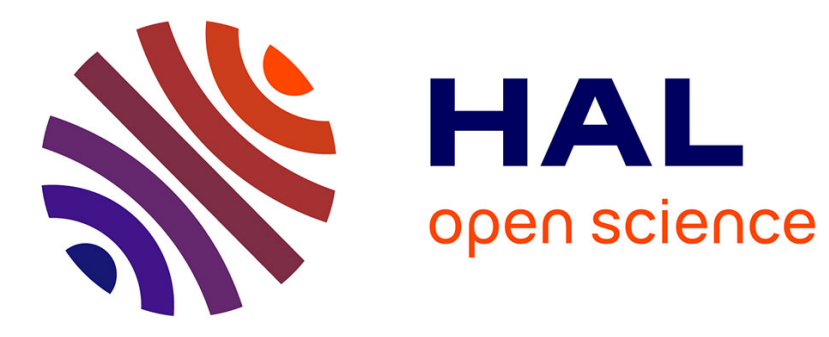

\title{
Chemical multi-contamination drives benthic prokaryotic diversity in the anthropized Toulon Bay
}

Benjamin Misson, Cédric Garnier, Béatrice Lauga, Duc Huy Dang, Jean-François Ghiglione, Jean-Ulrich Mullot, Robert Duran, Olivier Pringault

\section{- To cite this version:}

Benjamin Misson, Cédric Garnier, Béatrice Lauga, Duc Huy Dang, Jean-François Ghiglione, et al.. Chemical multi-contamination drives benthic prokaryotic diversity in the anthropized Toulon Bay. Science of the Total Environment, 2016, 556, pp.319 - 329. 10.1016/j.scitotenv.2016.02.038 . hal01826037

\section{HAL Id: hal-01826037 \\ https://hal-univ-tln.archives-ouvertes.fr/hal-01826037}

Submitted on 26 Jan 2022

HAL is a multi-disciplinary open access archive for the deposit and dissemination of scientific research documents, whether they are published or not. The documents may come from teaching and research institutions in France or abroad, or from public or private research centers.
L'archive ouverte pluridisciplinaire HAL, est destinée au dépôt et à la diffusion de documents scientifiques de niveau recherche, publiés ou non, émanant des établissements d'enseignement et de recherche français ou étrangers, des laboratoires publics ou privés. 


\section{Chemical multi-contamination drives benthic prokaryotic} diversity in the anthropized Toulon Bay

Benjamin Misson ${ }^{\mathrm{a}}$, Cédric Garnier ${ }^{\mathrm{a}}$, Béatrice Lauga ${ }^{\mathrm{b}}$, Duc Huy Dang ${ }^{\mathrm{a}, 1}$, Jean-François Ghiglione $^{d}$, Jean-Ulrich Mullot ${ }^{e}$, Robert Duran $^{b}$ and Olivier Pringault ${ }^{f, g}$

a PROTEE, EA 3819, Université de Toulon, CS 60584, 83041 Toulon Cedex 9, France

${ }^{b}$ Equipe Environnement et Microbiologie, Melody group, Université de Pau et des Pays de l'Adour, IPREM, UMR CNRS 5254, BP 11055, F-64013 Pau cedex, France

d Sorbonne Universités, UPMC Univ Paris 06, CNRS, Laboratoire d'Océanographie Microbienne (LOMIC) UMR 7621, Observatoire Océanologique, F-66650, Banyuls/mer, France;

${ }^{\text {e }}$ LASEM de Toulon, Base Navale Toulon, BP 61, 83800 Toulon Cedex 9, France

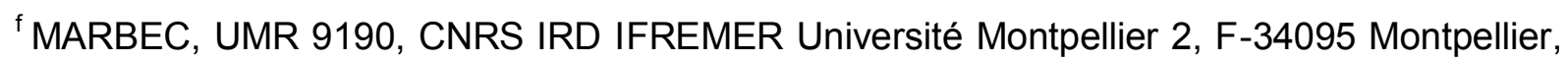
France

${ }^{g}$ Laboratoire de Biosurveillance de l'Environnement, Faculté des Sciences de Bizerte, Zarzouna 7021, Tunisie

1 Present address: Water Quality Center, Trent University, 1600 West Bank Drive, Peterborough, ON, Canada K9J 7B8

Corresponding author: misson@univ-tln.fr 


\section{ABSTRACT}

Investigating the impact of human activities on marine coastal ecosystems remains difficult because of the co-occurrence of numerous natural and human-induced gradients. Our aims were (i) to evaluate the links between the chemical environment as a whole and microbial diversity in the benthic compartment, and (ii) to compare the contributions of anthropogenic and natural chemical gradients to microbial diversity shifts. We studied surface sediments from 54 sampling sites in the semi-enclosed Toulon Bay (NW Mediterranean) exposed to high anthropogenic pressure. Previously published chemical data were completed by new measurements, resulting in an in depth geochemical characterization by 29 representative environmental variables. Bacterial and archaeal diversity was assessed by terminal restriction fragment length polymorphism profiling on a selection of samples distributed along chemical gradients. Multivariate statistical analyses explained from $45 \%$ to $80 \%$ of the spatial variation in microbial diversity, considering only the chemical variables. A selection of trace metals of anthropogenic origin appeared to be strong structural factors for both bacterial and archaeal communities. Bacterial terminal restriction fragment (T-RF) richness correlated strongly with both anthropogenic and natural chemical gradients, whereas archaeal T-RF richness demonstrated fewer links with chemical variables. No significant decrease in diversity was evidenced in relation to chemical contamination, suggesting a high adaptive potential of benthic microbial communities in Toulon Bay.

Key words: microbial ecotoxicology, multi-contamination, prokaryotic diversity, marine sediment 


\section{INTRODUCTION}

Marine coastal areas represent ecotones between continental and marine environments. Strong and natural coastal gradients (e.g. salinity, water inflows, bottom topography, sedimentation pattern, turbidity and nutrients) are known to shape the diversity of several organisms, ranging from fishes (Winemiller and Leslie, 1992) to bacteria (Ortega-Retuerta et al., 2013; Troussellier et al., 2002), including invertebrates (Waterkeyn et al., 2008). As a result, the functions of coastal ecosystems are largely driven by natural gradients (Sklar and Browder, 1998). Since coastal areas are of great interest to humans, they also face increasing human-induced chemical contamination resulting from watershed drainage, domestic and industrial waste waters and other direct inputs, such as biocides released by anti-fouling paints or fuel residues from shipping (e.g. Colombo et al., 2006; Daskalakis and Oconnor, 1995; Levin et al., 2009; Oursel et al., 2014, 2013). As a result, marine coastal areas are characterized by a complex set of chemical factors potentially affecting living organisms. Consequently, marine coastal ecosystems represent one of the most challenging environments for understanding the links between chemical composition and biological diversity.

Benthic archaea and bacteria are key microbial players in ecosystem functioning, because of their major roles in diverse biogeochemical cycles, particularly through carbon and nitrogen mineralization (Francis et al., 2005; Jørgensen, 2000) and toxic metals transformation, either directly (e.g. mercury methylation, Parks et al., 2013) or indirectly (e.g. formation of sulfide compounds after sulfide release by sulfate reduction, Jørgensen, 2000). However, little is known about the links between prokaryotes diversity and the global chemical composition of the sediment, including both the natural composition and anthropogenic chemical contaminants, in marine coastal areas. It was evidenced that early diagenesis, which is controlled by microbial activity, induced modifications to the characteristics of sedimentary organic matter (e.g. Burdige, 2007; Dang et al., 2014a) but also influenced the mobility of trace elements, such as trace metals/metalloids (e.g. Dang et al., 2015a, 2014b; Gendron et al., 1986), with significant seasonal variations. Moreover, the influence of microbial activity on 
metal speciation has been demonstrated, particularly for mercury speciation (Cossa et al., 2014; Duran et al., 2008) and organic tin degradation (Filipkowska et al., 2014; Pougnet et al., 2014) in coastal sediments. Our understanding of the influence of benthic microbial activity on the chemical composition of anthropized coastal sediment is thus progressing well. Nevertheless, the impact of the global chemical composition of sediment on benthic microbial communities is poorly documented. Some bacteria and microalgae were shown to resist or even benefit from high inorganic or organic contaminant concentrations (e.g. Edwards et al., 2013; Gauthier et al., 1992; Louati et al., 2013; Rensing et al., 2000). However, chemical pollution can affect the diversity and functions of prokaryotic communities (Abell et al., 2014; Scott et al., 2014), although the great adaptive skills of prokaryotes after long term exposure to chemical contaminants (Gillan et al., 2014) can lead us to observe no significant change in diversity (Besaury et al., 2014; Gillan et al., 2005), not even higher diversities (Bengtsson et al., 2013) in response to chemical pollution. Such influences result in spatial variability of microbial abundance and/or community composition in the environment, which can alter ecosystem functioning along the contamination gradients (Abell et al., 2014; Scott et al., 2014). Thus, in marine coastal ecosystems, the relative contributions of natural abiotic gradients and anthropogenic and multiple contamination gradients to the spatial variability of microbial diversity need to be further explored in order to better apprehend the ecological consequences of human-induced environmental changes.

The present study was held at Toulon Bay, a semi-enclosed coastal ecosystem experiencing very strong and multiple contaminations by metals, metalloids, organometallic and organic pollutants (Cossa et al., 2014; Dang et al., 2015a, 2014b; Pougnet et al., 2014; Tessier et al., 2011). While this ecosystem experiences multiple contamination gradients of several orders of magnitude, its relatively small size greatly limits other abiotic variations such as climate related parameters, hydrology and mean sediment composition (excluding pollutants). An indepth geochemical characterization of surface sediments and the genetic fingerprinting of archaeal and bacterial benthic communities sampled at numerous stations in Toulon Bay allowed us (i) to address the impact of the global chemical environment and then (ii) to 
compare the respective influence of a wide range of both natural and anthropogenic gradients on both local microbial genetic richness and spatial variations in microbial community structure. 


\section{MATERIALS AND METHODS}

\subsection{Study site and sediment sampling}

Sediments samples were collected at different locations of Toulon Bay, on the northwest Mediterranean coast. Its semi-close morphology associated with micro-tidal conditions and intermittent freshwater inputs (Nicolau et al., 2012), leads to relatively long water residence times (Dufresne et al., 2014). Consequently, numerous historic (e.g. World War II) and present $\left(1^{\text {st }}\right.$ French navy harbour, nautical traffic, tourism, urbanism, aquaculture, etc.) anthropogenic activities have resulted in a strong multi-contamination of the sedimentary compartment (Cossa et al., 2014; Dang et al., 2015a, 2014b; Pougnet et al., 2014; Tessier et al., 2011) and also of the water column (Jean et al., 2012, Dang et al., 2015b). A map of Toulon Bay including the location of the main towns and anthropogenic activities, is presented in figure 1A. The bay is separated into two basins by a sea wall: Little Bay $(\mathrm{LiB})$ on the northwestern side and Large Bay ( $\mathrm{LaB})$ on the southeastern part. Sediments were collected using an interface corer (equipped with 10-cm diameter and 1-m long Plexiglass tube, handled from a navy boat or divers) as previously described (Tessier et al., 2011) to collect sediments at 54 stations covering the whole bay (figure 1) .

\subsection{Chemical characterization of the sediments}

We compiled previously published data on the chemical characterization of the surface sediments, except for the organic pollutants (polycyclic aromatic hydrocarbons (PAHs), polychloro biphenylated (PCBs)). Briefly, the obtained surface sediments $(0-5 \mathrm{~cm})$ were analysed for (1) major constituents (major elements, particulate organic and inorganic carbon (POC, PIC), total phosphorus) and minor/trace elements (Dang et al., 2015a, 2014a, 2014b; Tessier et al., 2011); (2) methyl mercury (MMHg) (Cossa et al., 2014); and (3) tin and butyltin species (Pougnet et al., 2014). Full description of samples treatment and chemical analysis can be found in the cited references. Briefly, sediments were deep-frozen, freezedried, 2-mm sieved and kept deep frozen $\left(-18^{\circ} \mathrm{C}\right)$ until analysis. POC and PIC contents were determined using a TOC- $\mathrm{V}_{\mathrm{CSH}}$ analyzer (Shimadzu) coupled with a SSM-5000A module 
(Dang et al., 2014a; Tessier et al., 2011). Major elements and total phosphorus were measured by XRF (Philips PW 2400) equipped with a Rh-tube, on 50- $\mathrm{mm}$ crushed (on carbide tungsten rings mill, NAEF model M02) sediments (Tessier et al., 2011). Minor/trace elements were determined by High Resolution Inductively Coupled Plasma Mass Spectrometer (HR ICP-MS, Element 2, Thermo Finnigan) after aqua regia and microwave (Anton Paar Multiwave 3000) digestion of sediments (Dang et al., 2014b, 2015a; Tessier et al., 2011). Hg contents were determined by an advanced mercury analyzer AMA 254 (Leco Corporation) (Tessier et al., 2011). MeHg was analysed after propylation and isotopic dilution and detection by gas chromatography-ICP-MS (GC/ICP-MS, GC-Focus with X-series, Thermo Electron) (Cossa et al., 2014). Butyl-tin species contents were determined by GC/ICP/MS (Thermo X7 Series II) after extraction of butyl-Sn species by acetic acid (Pougnet et al., 2014). Moreover, 25 surface sediment samples from LiB (figure 1) were analysed for 17 PAHs (Acenaphthene, Anthracene, Benz[a]anthracene, Benzo[a]pyrene, Benzo[b]fluoranthene, Benzo[ghi]perylene, Benzo[k]fluoranthene, Chrysene, Dibenz[a,h]anthracene, Fluoranthene, Fluorene, Indeno[1,2,3-cd]pyrene, Naphthalene, Phenanthrene, Pyrene, 2-methylfluoranthene, 2-methylnaphthalene) and 8 PCBs (CB-28, CB-31, CB-52, CB-101, CB-118, CB-138, CB-153, CB-180), accordingly to the French standard AFNOR XP X33-012. Briefly, PAHs were extracted from $4 \mathrm{~g}$ of sediment using a mixture of hexane/acetone (50:50) assisted by ASE (ASE 200, Dionex), the obtained extract was then purified by solid-phase extraction (SPE, ASPEC XL, Gilson), concentrated $\left(50^{\circ} \mathrm{C}\right.$ under $\mathrm{N}_{2}$ flux), adjusted to $5 \mathrm{~mL}$ with acetonitrile/water (50/50) and PAHs concentrations were analysed by HPLC (Shimadzu, Prominence UFLC) with UV and fluorescence detection. Concerning PCBs, they were extracted from $7 \mathrm{~g}$ of sediments by using a mixture of hexane/acetone (50:50) assisted by ASE (ASE 200, Dionex) in the presence of $1 \mathrm{~g}$ of $\mathrm{Cu}$ powder. The obtained extract was then purified on SPE (ASPEC XL, Gilson), concentrated ( $50^{\circ} \mathrm{C}$ under $\mathrm{N}_{2}$ flux), and adjusted to $1 \mathrm{~mL}$ with hexane. CBs concentrations were analysed by GC/MS (Thermoelectron, Polaris Q) in negative chemical ionization mode. The accuracy 
of these protocols was validated using certified material (MRC 1941b and MRC 1944 for PAHs and CBs, respectively).

\subsection{DNA extraction and prokaryotic fingerprinting}

DNA was extracted from aliquots of lyophilized sediments (kept frozen at $-20^{\circ} \mathrm{C}$ ) from 38 samples from among the 54 described above (figure 1), covering the whole range of main sediment characteristics and chemical contaminants levels. Extractions were performed using the Power Soil DNA Extraction Kit (Mobio Laboratories, Carlsbad, CA) following the manufacturer's recommendations. Terminal Restriction Fragment Length Polymorphism (TRFLP) profiling was conducted on each sample after 16S rRNA gene amplification using primers 8F (Lane, 1991)/519R (Frank et al., 2013) labeled with FAM (5-carboxyfluorescein) and HEX (6-carboxy-1,4-dichloro-2',4', 5', 7'-tetrachlorofluorescein) fluorochromes respectively for Bacteria and 344F (Raskin et al., 1994)/915R (Stahl and Amann, 1991) labelled with FAM and HEX fluorochromes respectively for Archaea using AmpliTaq Gold® DNA Polymerase (Life technologies). For PCR amplification an initial denaturation step at $94{ }^{\circ} \mathrm{C}$ for 5 min was followed by 35 cycles of $94{ }^{\circ} \mathrm{C}$ denaturation for $45 \mathrm{~s}, 56{ }^{\circ} \mathrm{C}$ annealing for $45 \mathrm{~s}$, and $72{ }^{\circ} \mathrm{C}$ extension for $1 \mathrm{~min}$, and concluded with an extension at $72^{\circ} \mathrm{C}$ for $10 \mathrm{~min}$. PCR amplicons were cleaned using the GFX PCR DNA Purification kit (GE Fisher) and digested with the restriction endonucleases Hinfl for Bacteria and Taql for Archaea $\left(37^{\circ} \mathrm{C}, 3\right.$ h). T-RFLP profiles were obtained with a 3130xl Genetic Analyzer (Applied Biosystems) following the manufacturer's recommendations and analysed with GeneMapper®Software (Applied Biosystems). Using T-Rex software (Culman et al., 2009) raw data were normalized to account for differences in the amount of DNA loaded and terminal restriction fragments (TRFs) assigned to produce the final matrix.

\subsection{Data analysis and statistics}

The high spatial resolution maps allowed the establishment of surface-weighted average (SWA) trace metal/metalloids contents for Toulon Bay, i.e. the most representative 
concentration values on the entire bay scale (Dang et al., 2015a; Larrose et al., 2010; Tessier et al., 2011). The kriging gridding method of Surfer software (9.9 version) with default parameters was used to generate contour map and Matlab software (7.8 version) was used for data processing.

Using a principal component analysis (PCA) on 2 chemical characteristics (PIC, POC) and 31 major/minor/trace elements (Ag, Al, As, Ba, Be, Bi, Ca, Cd, Co, Cr, Cs, Cu, Fe, Hg, K, Li, $\mathrm{Mn}, \mathrm{Mo}, \mathrm{Ni}, \mathrm{P}, \mathrm{Pb}, \mathrm{Rb}, \mathrm{S}, \mathrm{Sb}, \mathrm{Sn}, \mathrm{Sr}, \mathrm{Ti}, \mathrm{TI}, \mathrm{U}, \mathrm{V}$ and $\mathrm{Zn}$ ) from 130 surface and deep sediments from Toulon Bay, Dang et al. (2015a) have evidenced 6 groups of elements: (1) the "marine" originated elements (Ca, PIC and $\mathrm{Sr}$ ), (2) the "terrigenous" elements, mainly representing clays ( $\mathrm{Al}, \mathrm{Be}, \mathrm{Cs}, \mathrm{Fe}, \mathrm{K}, \mathrm{Li}$ and $\mathrm{Rb}$ ), (3) "inorganic contaminants", i.e. elements mainly of anthropogenic origins ( $\mathrm{Ag}, \mathrm{Ba}, \mathrm{Bi}, \mathrm{Cd}, \mathrm{Cu}, \mathrm{Hg}, \mathrm{P}, \mathrm{Pb}, \mathrm{Sb}, \mathrm{Sn}, \mathrm{Ti}$ and $\mathrm{Zn}$ ), (4) inorganic trace elements having mainly "natural" origin, from terrigenous inputs $(\mathrm{Co}, \mathrm{Mo}, \mathrm{Ni}$, TI, U and V), (5) elements showing "mixed" anthropogenic and terrigenous origins (As, Cr, $\mathrm{Mn}$ and S), and (6) the POC. To illustrate these co-variations, the observed relationship between $\mathrm{PIC}$ and $\mathrm{Ca}, \mathrm{Rb}$ vs. $\mathrm{Al}, \mathrm{Bi}$ vs. $\mathrm{Pb}, \mathrm{Co}$ vs. $\mathrm{Ni}$ and $\mathrm{As}$ vs. $\mathrm{Cr}$ in the surface sediments dataset considered in the present study are shown in Fig. SI-1. In order to reduce the number of chemical variables for further statistical analysis, the elements of "marine" origin were then only represented by $\mathrm{Ca}$, the "terrigenous" elements by $\mathrm{Al}$ and $\mathrm{Fe}_{\text {; }}$ and the trace elements of "natural" origin by $\mathrm{Co}$ and $\mathrm{Ni}_{\text {; }}$ when $\mathrm{POC}$, "inorganic contaminants" and trace elements of "mixed" origin were all taken into consideration. Then, a $7^{\text {th }}$ group of "organometallic contaminants" was defined using: monomethylmercury ( $\mathrm{MMHg}$ ), tributyltin (TBT) and the sum of butyltin-species ( $\Sigma B T)$. Significant relationships observed between TBT and $\mathrm{SBT}$, and MMHg and $\mathrm{Hg}$ (Fig. SI-2) were evidenced by Pougnet et al. (2014) and Cossa et al. (2014) and suggested the strong influence of microbial communities on the sedimentary dynamics of these species. Finally, an $8^{\text {th }}$ group included the "organic contaminants" (PAHs and PCBs). Considering the significant correlations $\left(\mathrm{R}^{2}\right.$ ranging from 0.86 to 0.98 and from 0.95 to 0.99 for PAHs and PCBs respectively, data not shown) observed between each of the 17 measured PAHs and their sum ( $\mathrm{PAH})$, and between each 
of the 8 measured PCBs and their sum ( $\mathrm{PPCB})$, the present study only considered the following chemical variables: $\Sigma \mathrm{PAH}, \Sigma \mathrm{PCB}$, Fluoranthene and $\mathrm{CB}-153$ (being the most abundant PAH and PCB, accounting on average for $16 \%$ and $29 \%(\mathrm{~N}=26)$ of the $\Sigma \mathrm{PAH}$ and ¿PCB, respectively; figure SI-3).

This clustering of chemical variables highlighted five groups corresponding to the sediment type ("marine", "terrigenous", POC; and inorganic trace elements of "natural" or "mixed" origin) and three groups of anthropogenic contaminants ("inorganic", "organometallic" and "organic" elements/compounds), resulting in 29 representative chemical variables. The content ranges, median content and SWA (only for the 23 variables measured on all the sediments samples) values of these chemical variables are summarized in table 1.

Enrichment factors (EF) (Hilton et al., 1985) were calculated for trace metals/metalloids contaminants in order to distinguish anthropogenic pollution from the natural content of the sediment as described in Tessier et al. (2011). Briefly, the measured trace elements contents were normalized to the Al contents of the samples, and then compared with the geochemical background of the studied area for the same normalized metal content, according to the following equation:

$E F=\frac{(M E / A l)_{\text {sample }}}{(M E / A l)_{\text {background }}}$

where $\mathrm{Me}$ is the content of the corresponding trace metal/metalloid. The geochemical background was here estimated as the average of the three lowest calculated Me/AI ratios from 146 samples originating from surface and deep sediments (including ${ }^{210} \mathrm{~Pb}$-dated core sediments corresponding to the lowest contamination records, from Dang et al., 2015a and Tessier et al., 2011) of Toulon Bay. According to Sutherland (2000), significant enrichment levels are reached if $5<\mathrm{EF}<20$, and very high enrichment levels if $\mathrm{EF}>20$.

The toxic potential of the sediment was evaluated through comparison of the contents to effects range-low (ERL) and effects range-medium (ERM) guidelines, initially determined through toxicity evaluation on benthic invertebrates exposed to single contaminations (Long et al., 1995). Then, in order to assess the global toxic potential of the multi-contaminated 
sediments of Toulon Bay, the mean ERM quotient ( $m-E R M-Q)$ was calculated as described in Long et al. (1998), according to the following equation:

$m-E R M-Q=\frac{\sum_{i=1}^{n}\left(C_{i} / E R M_{i}\right)}{n}$

where $C_{i}$ is the sediment content of compound $i, \mathrm{ERM}_{\mathrm{i}}$ is the ERM for compound $i$ and $n$ is the number of compounds.

Local (alpha) diversity indexes (number of terminal restriction fragments (T-RF richness), Pielou's Evennes and Shannon H') were computed using PRIMER 6 software (v6.1.13, Clarke, 1993).

Spatial variations of both chemical composition and microbial communities' T-RF structure (beta-diversity) were analysed through quantitative distance analyses, conducted using PRIMER 6 software. Chemical Gower similarities were computed from median normalized substance contents in order to properly compare minor and major element content'- variation. Biological Bray-Curtis similarities were computed from $\operatorname{asin}(\sqrt{x})$ normalized T-RFLP data (Legendre and Legendre, 1998). Differences between samples originating from LiB or LaB were visualized through principal coordinate analysis (PCoA) and tested by one-way permutational multivariate analysis of variance (PERMANOVA) with Rstudio (RStudio Team, 2015, package vegan).

Correlations between biological and chemical similarities were assessed by Mantel's test using XLStat (version 2010.3.03, Addinsoft, Paris, France). Other correlations were tested with Spearman's correlation test using Rstudio (RStudio Team, 2015, packages stats and psych)

Variation partitioning through direct multivariate canonical correspondence analysis (CCA) was used to compare the respective contributions of anthropogenic contaminants and sediment type to the spatial variability of archaeal and bacterial community structure. In order to avoid using multicolinear variables and thus overestimating contributions to the biological variance, covariance analyses were performed and variables presenting variance inflation 
factors higher than 10 were excluded from the dataset. Covariance analysis and CCA were performed with Rstudio (RStudio Team, 2015, packages vegan, $H H$ and $u s d m$ ). 


\section{RESULTS}

\subsection{Abiotic characterization of the sediments}

A set of chemical gradients was observed in surface sediments of Toulon Bay. Groups related to sediment origin and natural and mixed trace elements presented narrow to moderate content gradients (table 1), with Al (figure 2A) and $\mathrm{Ca}$ (figure SI-4A) presenting clear terrestrial-marine gradients resulting in an opposite relationship between these 2 elements (figure SI-5). Among inorganic contaminants (ex. Cd, figure 2B), the strongest spatial variations in concentrations was observed for $\mathrm{Cu}, \mathrm{Hg}, \mathrm{Sn}$ and $\mathrm{Zn}$, with about 55- to 900-fold content ranges (table 1). Organo-metals also presented very wide content gradients, with a 13500-fold range for TBT and an approximately 80 -fold range for $\mathrm{MMHg}$ (table 1). Organic contaminations followed moderate to strong gradients with approximately 15 to 89 fold content ranges for $\Sigma \mathrm{PAH}$ (figure SI-4B), fluoranthene, POC, CB-153 (figure 2C) and $\Sigma$ PCB, respectively (table 1 ). Most of the natural or mixed trace elements and inorganic, organometallic or organic contaminants presented similar distribution, their content values being the highest in the northern part of LiB and gradually decreasing toward the south-east and the open sea (for representative examples, see figures 2B, 2C and SI-4A). Tin, POC fluoranthene and $\mathrm{PAH}$ did not follow this trend, presenting more random variations (figure SI-4B).

Considering most of these representative physical-chemical parameters together (except for TBT, $\Sigma$ BT, fluoranthene, $\Sigma$ PAH, CB-153 and $\Sigma$ PCB, which were not measured in all of the sampling sites), spatial variations in the global chemical signature of the sediment (i.e. considering all 8 of the clusters identified above) were assessed by calculating Gower similarities. This distance analysis demonstrated important variations of sediment chemical composition with reference to the less contaminated sites (two stations located south-east and south-west of Toulon bay, respectively, away from most of the human activities centers), with an offshore-to-coast gradient following the distribution of the main contaminants (figure 2D). Very important shifts of chemical signature were especially recorded in LiB, the most 
anthropized area, resulting in a very low degree of similarity (decreasing to $28 \%$ ) compared with the mouth of the bay. Similar gradients were globally observed when computing Gower distances for the chemical signatures of the sediment type and the anthropogenic contaminants, with significant local shifts observed mainly in the northern LiB and near the coasts of St. Mandrier's peninsula (figure SI-4C and D). Specific distance assessments with fewer sampling points to include organic contaminants (24 sampling sites) or TBT and $\Sigma$ BT (29 sampling sites) confirmed this trend (data not shown).

\subsection{Contamination levels and potential toxicity}

In order to better evaluate sediment contamination by trace metals, Al-normalized enrichment factors (EF) were calculated to compare the surface sediment concentrations of $\mathrm{Ag}, \mathrm{As}, \mathrm{Ba}, \mathrm{Bi}, \mathrm{Cd}, \mathrm{Co}, \mathrm{Cr}, \mathrm{Cu}, \mathrm{Hg}, \mathrm{Ni}, \mathrm{P}, \mathrm{Pb}, \mathrm{Sb}, \mathrm{Sn}, \mathrm{Ti}$ and $\mathrm{Zn}$ with the geochemical background of Toulon bay (table 1). Mercury was clearly the most enriched inorganic contaminant in these sediments, reaching an EF as high as 1200 and presenting very high enrichment levels (EF $>20$ ) in approximately $80 \%$ of the surface sediment area of Toulon Bay (table 1). A few other inorganic contaminants ( $\mathrm{Ag}, \mathrm{Bi}, \mathrm{Cu}, \mathrm{Pb}, \mathrm{Sb}, \mathrm{Sn}$; and $\mathrm{Zn}$ ) presented significant enrichment levels $(5<\mathrm{EF}<20$ ) over $10 \%$ to $90 \%$ of the surface of Toulon Bay and very high local enrichment levels, reaching up to 50 and 54 for $\mathrm{Sn}$ and $\mathrm{Cu}$, respectively. As detailed in table 1, the highest recorded concentrations of five inorganic contaminants (As, $\mathrm{Cu}, \mathrm{Hg}, \mathrm{Pb}$ and $\mathrm{Zn}$ ) and of two organic contaminants (fluoranthene and $\Sigma \mathrm{PCB}$ ) surpassed their ERM values. Moreover, approximately $50 \%$ of the surface of Toulon Bay presented $\mathrm{Hg}$ contents overpassing the corresponding ERM. Then, m-ERM-Q was calculated in order to compare the toxic potential of the different sediment samples. When considering only trace metals, $26.6 \%$ of the whole surface of Toulon bay presented m-ERM-q values above 0.5 , representing a probability of being toxic of approximately $50 \%$ or higher. Moreover, more than $80 \%$ of the surface presented $m-E R M-Q$ values above 0.5 . According to spatial variation in metals-based $m-E R M-Q$, the highest toxic potentials were observed in 
the northern part of $\mathrm{LiB}$ (figure $2 \mathrm{E}$ ). Including organic pollutants also confirmed this trend (figure SI-4E).

\subsection{Local microbial diversity variations}

Bacterial T-RF richness ranged between 14 and 40 OTUs. It appeared to be higher in LiB, and decreased gradually through $\mathrm{LaB}$ where it reached its minimum before increasing slightly towards the open sea (figure $3 \mathrm{~A}$ ). Archaeal T-RF richness appeared to be smaller with 4 to 13 T-RFs, and varied in a more chaotic way with important changes between very close sampling stations (figure 3B). Shannon indexes calculated from T-RFLP data provided very similar results $\left(H^{\prime}\right.$ ranging from 1.34 to 2.43 for archaea and from 2.60 to 3.52 for bacteria) and were very strongly correlated to richness $\left(R^{2}=0.96\right.$ for archaea and 0.94 for bacteria). Evenness demonstrated very low spatial variations (ranging from 0.91 to 0.995 for both bacteria and archaea) and was not correlated with Shannon $H^{\prime}$ variations $\left(R^{2}<0.1\right.$ for both archaea and bacteria), thus highlighting the importance of richness in bacterial and archaeal Shannon index variations among sediment samples. Hence, local microbial diversity will be represented by genetic richness in further analyses.

Bacterial T-RF richness was positively correlated with parameters related to "terrigeneous" elements $(\mathrm{Al}, \mathrm{Fe})$, one "natural" trace element $(\mathrm{Ni})$, trace elements of "mixed" origin ( $\mathrm{As}, \mathrm{Cr}$ and S), some anthropogenically enriched toxic trace metals ( $\mathrm{Ag}, \mathrm{Cu}, \mathrm{Hg}$ and $\mathrm{Zn}$ ), organometallic contaminants (MMHg, TBT and $\Sigma B T$ ), some organic contaminants (CB-153, $\Sigma \mathrm{PCB})$ and metal-based $\mathrm{m}-\mathrm{ERM}-\mathrm{Q}$, whereas it was correlated negatively with marine elements (Ca), Co and $\mathrm{Ni}(p<0.05$, table 2).

Archaeal genetic richness proved to be linked to fewer environmental parameters: it was also positively correlated with terrigeneous elements ( $\mathrm{Al}, \mathrm{Fe})$, one trace element of mixed origin $(\mathrm{Cr})$, some anthropogenically enriched toxic trace metals $(\mathrm{Bi}, \mathrm{Cu}, \mathrm{Hg}, \mathrm{Pb}$ and $\mathrm{Zn})$, organometallic contaminants (MMHg, TBT and $\Sigma$ BT $)$ and $m$-ERM-Q values $(p<0.05$, table 2). 
Hence, in Toulon Bay, both bacterial and archaeal T-RF richness appeared to be higher in sediments influenced by terrestrial inputs; enriched in many toxic substances, and thus presenting a high toxic potential. However, for most of the chemical substances presenting significant correlations with the T-RF richness of both microbial communities, the correlations were weaker and less significant for archaea. Particulate organic carbon, $\mathrm{Mn}$ and $\mathrm{P}$ contents in the sediments did not appear to be linked with either bacterial or archaeal T-RF richness $(p>0.05$, table 2$)$

\subsection{Spatial variations in microbial community structure}

Beta- diversity analysis (PERMANOVA) of the bacterial community highlighted a clear segregation ( $p=0.001$ ) of the samples originating, on one hand, from LiB and, on the other hand, from $\mathrm{LaB}$ and towards the open sea (figure $4 \mathrm{~A}$ ). With reference to the less contaminated sites located outside of Toulon Bay, the bacterial similarity appeared very low (decreasing to approximately $20 \%$ ) upon entry into LaB, then increased slightly but varyed strongly again between very close stations westward (figure 3C). Complementary analysis with reference to the most contaminated site (MIS station, in the northern part of LiB, figure SI-4F) demonstrated very strong differentiation towards the south of the bay, with low similarity (decreasing to $50 \%$ ) between sites distant from barely more than $1 \mathrm{~km}$. In contrast, no evident clustering according to geographical origin $(p=0.052)$ could be observed for the archaeal community (figure 4B). The archaeal similarities were globally higher and less variable, with the strongest shifts being observed in $\mathrm{LiB}$ and near the mouth eastward (figure 3D).

Both archaeal and bacterial similarities were negatively correlated with the geographical distance between sites $\left(n=703\right.$, archaea: $r=-0.286, p<10^{-4}$, bacteria: $r=-0.285, p<10^{-4}$ ), and positively correlated to the sediment type's chemical signature $(n=703$, archaea: $r=$ 0.195, $p<10^{-4}$, bacteria: $r=0.209, p<10^{-4}$ ). However, the spatial variation in the global chemical signature only appeared very weakly correlated with the bacterial similarities $(\mathrm{n}=$ $703, r=0.094, p=0.014)$ and not significantly correlated with the archaeal similarities $(n=$ 
$703, p>0.05)$. The anthropogenic contaminants' chemical signature did not demonstrate any significant correlation with biological similarities $(n=703, p>0.05)$. The same trends were recorded with reduced datasets including BT species $(n=276)$ or organic contaminants $(n=$ 171), while archaeal similarities only correlated significantly with the geographic distances between sites (data not shown).

When considering all of the sampling stations $(n=38)$, the combination of sediment type (represented by $\mathrm{Ca}, \mathrm{Co}, \mathrm{As}, \mathrm{Cr}, \mathrm{Mn}, \mathrm{S}$ and $\mathrm{POC}$ ) and anthropogenic contaminants (Ba, Cd, $\mathrm{Hg}, \mathrm{P}, \mathrm{Sb}, \mathrm{Sn}$ and $\mathrm{Ti}$ ) explained $46 \%$ of the bacterial community's structural variation, each of them accounting for $26 \%$ on its own. Similarly, this dataset explained $51 \%$ of the archaeal community's structural variation, with anthropogenic contaminants explaining a little less than sediment type (26\% and $26 \%$, respectively). Including BT species did not significantly increase the contribution of the anthropogenic contaminants, since TBT and $\Sigma$ BT never explained more than $5 \%$ of the variability of the archaeal and bacterial communities' structure, far less than the other contaminants, which contributed up to $9 \%$ in the same dataset $(n=24)$. However, the global statistical contribution of the chemical dataset to the biological variation rose to $60 \%$ for both bacteria and archaea. Similarly, CB-153 and $\Sigma$ PCB proved to be the least important statistical contributors to biological variation, with contributions ranging between $4 \%$ and $6 \%$, whereas other single contaminants could explain up to $13 \%$. On the contrary, fluoranthene and $\Sigma \mathrm{PAH}$ contributed significantly (between $6 \%$ and $10 \%$ ), and appeared to be among the four best statistical contributors of all the contaminants in the corresponding dataset $(n=19)$. Within this reduced dataset, the global statistical contribution to biological variation reached $85 \%$ and $78 \%$ for bacteria and archaea, respectively. 


\section{DISCUSSION}

Marine coastal areas are subject to various natural and anthropogenic gradients. The benthic compartment of Toulon Bay illustrates well this general observation with gradients of POC content, sediment origin and multiple contaminations. In the literature, previous attempts to understand the contributions of the various factors shaping prokaryotic communities in different ecosystems mainly focused on the relative contributions of bottom-up and top-down variables to better understand food-web functioning (e.g. Berdjeb et al., 2011; Salcher, 2013; Van Wambeke et al., 2009) or on the influence of chemical pollutants through ecotoxicological approaches (e.g. Besaury et al., 2014; Duran et al., 2015; Kostka et al., 2011; Paisse et al., 2011; Quillet et al., 2012; Rasmussen and Sorensen, 2001). In this study, we chose to investigate the influence of the abiotic environment as a whole on microbial communities by considering together both potentially toxic contaminants and natural substances from various origins. The usefulness of such a global approach was demonstrated in this study by the major contribution of the chemical composition of the sediment in shaping benthic microbial communities of Toulon Bay. Indeed, from approximately $45 \%$ to more than $80 \%$ of the variability of bacterial and archaeal community structure could be statistically explained by a selection of chemical variables. Thus, a significant part of this variability remained statistically unexplained in our study, corresponding to some abrupt shifts that were observed in close and chemically similar sampling sites. This could be partly due to biotic factors, such as predation or viral lysis pressures, which are well known for their influence on prokaryotic community abundance and structure (Ben Said et al., 2015; Louati et al., 2013; Ram et al., 2014; Sauret et al., 2015) but were not investigated in this work.

Investigating global chemical signatures also proved to be valuable through the significant links that were observed between biological and chemical distances. Interestingly, neither the global chemical distance between the different sampling sites, nor the distance related to anthropogenic contaminants appeared strongly linked to biological distances, whereas geographical distances demonstrated stronger links with biological ones. This observation 
tends to demonstrate that, in this contaminated sediment, local selective pressures are stronger than the dispersal rate of benthic microbial communities, in spite of the very limited geographic scale. The positive relationship between biological distances and the chemical distance related to sediment type (including its marine or terrestrial origin) suggests that benthic microbial dispersal would be limited to sediment transport processes, which could promote strong spatial differentiation. However, the high connectivity through the water column within this marine coastal area, with a mean annual water exchange time of 3.4 days, makes this hypothesis unlikely (Dufresne et al., 2014). Thereafter, high dispersal but low survival of benthic microorganisms, because of major chemical shifts between the origin and end point environments, appears to be a more reliable hypothesis. Future deep taxonomic investigations will help to test these two hypotheses.

Thus, when facing the complexity of chemical variable interactions, such as the antagonistic effects of nutrients and pollutants, an in-depth geochemical characterization of the environment appears useful for providing a holistic and detailed chemical signature of the samples. Then comparing this global chemical signature to other environmental constraints, such as biotic interactions, appears to be a promising approach to understanding the ecology of microorganisms and the influence of the human footprint on ecosystem functioning.

Another striking result of this study came from multivariate analyses and linear regression analyses to evaluate the relative contributions of different variable classes to the observed biological variation. Among the abiotic parameters measured, metallic contamination clearly appeared to be an influential factor in shaping benthic prokaryote community structure in Toulon Bay. Indeed, as demonstrated by partial CCA results, at least $26 \%$ of the spatial variation in bacterial and archaeal community structure could be explained by a selection of trace metal contaminants. The gradient of benthic contamination in Toulon Bay by such pollutants includes both very low concentrations (i.e., close to the geochemical background of the region) and dramatic enrichments (e.g., Hg contamination), when compared with other ecosystems (for a more detailed comparison, see Tessier et al., 2011). Then, considering the 
panel of potential toxic effects these pollutants are known to have on microorganisms (for review, see Gadd, 2000; Nies, 1999), observing biological gradients in Toulon Bay appears logical. These results supported the intention to use bacterial communities as sensitive indicators of contaminant stress for use as an environmental monitoring tool (Sun et al., 2012). However, we did not observe any reduction in prokaryotic T-RF richness where trace metals and organometallic substances were the most enriched. On the contrary, we observed higher bacterial richness in the north-western bay, the most polluted area. This observation was confirmed by numerous positive, strong and significant correlations of T-RF richness with the concentrations of metallic and organometallic pollutants. In the same way, strong and positive correlations were also observed between T-RF richness and the toxic potential of the sediment estimated by the $m-E R M-Q$. However, caution is needed as this index is based on the sensitivity of macroorganisms rather than that of microorganisms (Long et al., 1998). Therefore, $m-E R M-Q$ is not well suited for predicting microbial community responses to chemical contaminations. Whereas metals and organometallic substances are well known for their toxic effects, their high concentrations were associated with a higher microbial richness. This striking relation tends to contradict the global erosion of marine biodiversity caused by anthropogenic inputs in the marine environment (Johnston and Roberts, 2009). However, the responses of microbial diversity to contaminants are more complex than those of marine macrobiota and similar observations have been reported in other marine coastal sediments (Duran et al., 2015; Li et al., 2013; Paissé et al., 2008).

One way to explain this contradiction relies on the intermediate disturbance hypothesis (IDH), which predicts the highest diversity for disturbances of intermediate frequency and intensity (Connell, 1978). Indeed, although concentrations of the pollutants observed in Toulon Bay can strongly disturb macroorganisms due to bioaccumulation and lower reproduction rates, they may induce a lower disturbance to the microbiota that grow faster and is able to resist and transform metal and organo-metallic substances (Nies, 1999). Moreover, the most enriched pollutants in the sediments of Toulon Bay are historical contaminants that have been present in excess for several decades (Pougnet et al., 2014; 
Tessier et al., 2011). This stability of the contamination level at the scale of microbial lifetime could therefore no longer represent a disturbance with respect to the IDH. Indeed, the bacterial community might have evolved and could now be particularly adapted to such an environmental stress, as observed in similar ecosystems impacted by metallic pollutions (e.g. Besaury et al., 2014). In chronically polluted systems, diversity indexes may be a nonadapted indicator of ecosystem stress as it can recover due to the divergence and proliferation of tolerant species (Gillan et al., 2005).

Organic contaminants appeared to be a less influential environmental stress on benthic prokaryote communities than metallic and organo-metallic contaminations in Toulon Bay sediments by statistic disentangling. Indeed, only a few links between organic contamination and prokaryote T-RF richness were observed in the sediment of Toulon Bay. Moreover, the contribution of organic contaminants to beta diversity patterns appeared limited. This observation is quite surprising when considering the relatively high concentrations measured in comparison to other sites and with reference to sediment quality guidelines (e.g. Gao et al., 2013; Long et al., 1998; Wolska et al., 2014). Moreover, several studies reported decreases, or at least very significant shifts, in microbial diversity in response to PAHs or PCBs contamination (e.g. Correa et al., 2010; Guazzaroni et al., 2013). This could be explained by the difference of more than one order of magnitude observed between the respective extents of contamination gradients of metallic and organic pollutants. The influence of organic contamination could thus be hidden by that of toxic trace metals. Nevertheless, as for trace metals, organic contaminations appeared to be positively related to prokaryote T-RF richness in Toulon Bay. Similar observation were previously reported in other ecosystems (Bengtsson et al., 2013), which could indicate a characteristic feature of contaminated sites with multiple contaminant types. Indeed, microorganisms are also known for their ability to grow on organic substrates, and especially PAH. Organic and more or less biodegradable contamination could thus increase the diversity of carbon resources for heterotrophic prokaryotes, creating new ecological niches. Thus, in agreement with IDH, 
organic contamination could partly explain the higher microbial richness found in the northwestern part of the bay as previously demonstrated (Bengtsson et al., 2013). Organic contamination could actually counterbalance the degradation of microbial diversity that could occur because of toxic metal enrichment, and finally reduce the extent of disturbance of these microorganisms.

The chemical gradients observed in the sediment of Toulon Bay did not present the same relations with the archaeal and bacterial benthic communities. This observation suggests differential responses of bacteria and archaea to this kind of chemical contamination. The spatial variations of archaeal T-RF richness were weaker than for bacteria, without a significant increase in the most polluted area, and demonstrated fewer and weaker links to the abiotic variables recorded, especially those corresponding to the sediment origin or to biologically relevant substances (POC, $\mathrm{S}$ and $\mathrm{Mn}$ ). Although the low number of archaeal $\mathrm{T}$ RFs detected could raise some methodological concerns, such as partial recovery of the archaeal community, the validation of the method in various previous studies (e.g. Stevenson et al., 2014) tends to invalidate this argument. Moreover, the weak relation between archaeal T-RF richness and the chemical substances measured is counterbalanced by the explanation of $26 \%$ to nearly $50 \%$ of the spatial variation of archaeal community structure by anthropogenic contaminants, as observed for the bacterial community. This observation could indicate that, whether or not the richness of the community was only poorly affected, its composition was likely more affected. From an ecological point of view, metal resistance in archaea and bacteria involves similar enzymatic responses (Bini, 2010), but archaea are known to predominate in extreme environments, especially where they are exposed to particularly high metal stress as in extremely acidic ecosystems (Baker and Banfield, 2003; Bini, 2010; Edwards et al., 2000). The question arises as to whether archaeal communities could present different and more widespread adaptive strategies than bacterial communities when facing multi-contaminations, especially the combination of organic, organometallic and inorganic contaminants. Further inventories of structural and functional diversity of bacteria 
and, above all, archaea are now required to explain the different trends we observed in this study between these communities.

Whether inorganic, organometallic or organic, the influence of a pollutant or chemical cocktail depends on its bioavailability. Although not studied in this work, Dang et al. (2014b, 2015a) have previously demonstrated that trace metals and metalloids could be highly mobilized from particles to pore water in surface sediments $(0-10 \mathrm{~cm})$, and that this mobilization could vary throughout the year. This suggests a potentially high bioavailability of inorganic contaminants in the sediment of Toulon Bay, and tends to support the hypothesis of welladapted communities. Thus the observed link between the mobility of inorganic contaminants and diagenesis activity throughout the seasons (Dang et al., 2014b, 2015a) also suggests that, in addition to being well adapted, microbial communities could drive the fate of these contaminants in the sediments of Toulon Bay. Now, investigating microbial community composition and focusing on functional communities with higher resolution methods under controlled conditions could help to shed the light on these different interactions between chemical contamination and microbial communities, as well as on potential cross-interactions between contaminant types.

\section{CONCLUSION}

Through this study, we have demonstrated the strong influence of the sediments' chemical signature on marine coastal benthic prokaryotic community diversity. In the sediments of Toulon Bay, the influence of such a chemical signature appeared to be mainly related to contamination gradients of trace metal and organo-metallic compounds, which proved to be strongly related to spatial variation in alpha and beta diversity of bacteria, and to a lesser extent, of archaea. Although bacterial and archaeal diversity appeared to be linked to this chemical signature, the major contamination gradients in Toulon Bay surface sediments did not appear to have resulted in diversity loss. On the contrary, bacterial richness seemed to 
be higher in the most polluted areas. The underlying ecological adaptive processes and the cross interactions between the multiple pollutant classes now require further clarification.

The current socio-economical context leads more and more scientists to focus on the consequences of human-related inputs for the environment, and especially on the threat they represent to living organisms and natural communities. For instance, it was recently demonstrated that the high $\mathrm{Pb}$ levels observed both in farmed and wild mussels from Toulon Bay, mostly originate from $\mathrm{Pb}$ sediment contamination, evidencing a clear link between the contaminated abiotic compartment and biotic species (Dang et al., 2015b). However, microorganisms are also well known for their role in the transformation of chemical contaminants, and especially in the geochemistry of toxic trace metals. Our work, in which no apparent toxic effect was observed in spite of very high contamination levels, reminds us how difficult it can be to evaluate which component, i.e., the chemical or the microbiological environment, influences the other to the greatest extent, even in multi-contaminated sites. The microbial contribution to the geochemical cycles of trace metals is still of major interest, and this study illustrates the need for better understanding to fully elucidate the consequences of toxic trace metal inputs to biodiversity. Further in-depth analyses of structural and functional diversities within microbial communities will help in identifying key species and adaptive mechanisms.

\section{ACKNOWLEDGEMENTS}

This study was performed in the framework of MerMex-WP3-C3A research program (part of the international IMBER project), CARTOCHIM and CARTOC research programs (funded by "Toulon-Provence-Méditerranée (TPM)", the "Région PACA", and "I’Agence de l'Eau RhôneMéditerranée et Corse"). The authors wish to thank the French Navy for diving and sampling assistance as well as the LASEM-Cherbourg laboratory (Aline Olivier, Laurent Lacombe) for PAHs and CBs analysis on sediments. We acknowledge the technical assistance of Claire Gassie (EEM) and the Regional Platform for Environmental Microbiology PREMICE supported by the Aquitaine Regional Government Council (France), the urban community of 
Pau-Pyrénées (France) and the CNRS. The English grammar and syntax of the manuscript have been revised by Proof-Reading-Service.com

\section{REFERENCES}

Abell, G.C.J., Ross, D.J., Keane, J., Holmes, B.H., Robert, S.S., Keough, M.J., Eyre, B.D., Volkman, J.K., 2014. Niche Differentiation of Ammonia-Oxidising Archaea (AOA) and Bacteria (AOB) in Response to Paper and Pulp Mill Effluent. Microb. Ecol. 67, 758768. doi:10.1007/s00248-014-0376-7

Baker, B.J., Banfield, J.F., 2003. Microbial communities in acid mine drainage. FEMS Microbiol. Ecol. 44, 139-152. doi:10.1016/S0168-6496(03)00028-X

Bengtsson, G., Törneman, N., De Lipthay, J.R., Sørensen, S.J., 2013. Microbial diversity and $\mathrm{PAH}$ catabolic genes tracking spatial heterogeneity of PAH concentrations. Microb. Ecol. 65, 91-100. doi:10.1007/s00248-012-0112-0

Ben Said, O., Louati, H., Soltani, A., Preud'homme, H., Cravo-Laureau, C., Got, P., Pringault, O., Aissa, P., Duran, R., 2015. Changes of benthic bacteria and meiofauna assemblages during bio-treatments of anthracene-contaminated sediments from Bizerta lagoon (Tunisia). Environ. Sci. Pollut. Res. Int. doi:10.1007/s11356-015-41057

Berdjeb, L., Ghiglione, J.-F., Jacquet, S., 2011. Bottom-up versus top-down control of hypoand epilimnion free-living bacterial community structures in two neighboring freshwater lakes. Appl. Environ. Microbiol. 77, 3591-3599. doi:10.1128/AEM.0273910

Besaury, L., Ghiglione, J.-F., Quillet, L., 2014. Abundance, activity, and diversity of archaeal and bacterial communities in both uncontaminated and highly copper-contaminated marine sediments. Mar. Biotechnol. N. Y. N 16, 230-242. doi:10.1007/s10126-0139542-z

Bini, E., 2010. Archaeal transformation of metals in the environment. FEMS Microbiol. Ecol. 73, 1-16. doi:10.1111/j.1574-6941.2010.00876.x

Burdige, D.J., 2007. Preservation of Organic Matter in Marine Sediments: Controls, Mechanisms, and an Imbalance in Sediment Organic Carbon Budgets? Chem. Rev. 107, 467-485. doi:10.1021/cr050347q

Clarke, K.R., 1993. Non-parametric multivariate analyses of changes in community structure. Aust. J. Ecol. 18, 117-143. doi:10.1111/j.1442-9993.1993.tb00438.x

Colombo, J.C., Cappelletti, N., Lasci, J., Migoya, M.C., Speranza, E., Skorupka, C.N., 2006. Sources, vertical fluxes, and equivalent toxicity of aromatic hydrocarbons in coastal sediments of the Rio de la Plata Estuary, Argentina. Environ. Sci. Technol. 40, 734740. doi:10.1021/es051672y

Connell, J.H., 1978. Diversity in tropical rain forests and coral reefs. Science 199, 13021310. doi:10.1126/science.199.4335.1302

Correa, P.A., Lin, L., Just, C.L., Hu, D., Hornbuckle, K.C., Schnoor, J.L., Van Aken, B., 2010. The effects of individual PCB congeners on the soil bacterial community structure and the abundance of biphenyl dioxygenase genes. Environ. Int. 36, 901-906. doi:10.1016/j.envint.2009.07.015

Cossa, D., Garnier, C., Buscail, R., Elbaz-Poulichet, F., Mikac, N., Patel-Sorrentino, N., Tessier, E., Rigaud, S., Lenoble, V., Gobeil, C., 2014. A Michaelis-Menten type equation for describing methylmercury dependence on inorganic mercury in aquatic sediments. Biogeochemistry 119, 35-43. doi:10.1007/s10533-013-9924-3

Culman, S.W., Bukowski, R., Gauch, H.G., Cadillo-Quiroz, H., Buckley, D.H., 2009. T-REX: software for the processing and analysis of T-RFLP data. BMC Bioinformatics 10, 171. doi:10.1186/1471-2105-10-171 
Dang, D.H., Lenoble, V., Durrieu, G., Mullot, J.-U., Mounier, S., Gamier, C., 2014a. Sedimentary dynamics of coastal organic matter: An assessment of the porewater size/reactivity model by spectroscopic techniques. Estuar. Coast. Shelf Sci. 151, 100111. doi:10.1016/j.ecss.2014.10.002

Dang, D.H., Lenoble, V., Durrieu, G., Omanović, D., Mullot, J.-U., Mounier, S., Garnier, C., 2015a. Seasonal variations of coastal sedimentary trace metals cycling: insight on the effect of manganese and iron (oxy)hydroxides, sulphide and organic matter. Mar. Pollut. Bull. 92, 113-124. doi:10.1016/j.marpolbul.2014.12.048

Dang, D.H., Schäfer, J., Brach-Papa, C., Lenoble, V., Durrieu, G., Dutruch, L., Chiffoleau, J.F., Gonzalez, J.-L., Blanc, G., Mullot, J.-U., Mounier, S., Garnier, C., 2015b. Evidencing the Impact of Coastal Contaminated Sediments on Mussels Through $\mathrm{Pb}$ Stable Isotopes Composition. Environ. Sci. Technol. 49, 11438-11448. doi:10.1021/acs.est.5b01893

Dang, D.H., Tessier, E., Lenoble, V., Durrieu, G., Omanović, D., Mullot, J.-U., Pfeifer, H.-R., Mounier, S., Garnier, C., 2014b. Key parameters controlling arsenic dynamics in coastal sediments: An analytical and modeling approach. Mar. Chem. 161, 34-46. doi:10.1016/j.marchem.2014.02.005

Daskalakis, K., Oconnor, T., 1995. Distribution of Chemical Concentrations in Us Coastal and Estuarine Sediment. Mar. Environ. Res. 40, 381-398. doi:10.1016/01411136(94)00150-N

Dufresne, C., Duffa, C., Rey, V., 2014. Wind-forced circulation model and water exchanges through the channel in the Bay of Toulon. Ocean Dyn. 64, 209-224. doi:10.1007/s10236-013-0676-3

Duran, R., Bielen, A., Paradžik, T., Gassie, C., Pustijanac, E., Cagnon, C., Hamer, B., Vujaklija, D., 2015. Exploring Actinobacteria assemblages in coastal marine sediments under contrasted Human influences in the West Istria Sea, Croatia. Environ. Sci. Pollut. Res. Int. doi:10.1007/s11356-015-4240-1

Duran, R., Ranchou-Peyruse, M., Menuet, V., Monperrus, M., Bareille, G., Goni, M.S., Salvado, J.C., Amouroux, D., Guyoneaud, R., Donard, O.F.X., Caumette, P., 2008. Mercury methylation by a microbial community from sediments of the Adour Estuary (Bay of Biscay, France). Environ. Pollut. 156, 951-958. doi:10.1016/j.envpol.2008.05.007

Edwards, C.D., Beatty, J.C., Loiselle, J.B.R., Vlassov, K.A., Lefebvre, D.D., 2013. Aerobic transformation of cadmium through metal sulfide biosynthesis in photosynthetic microorganisms. Bmc Microbiol. 13, 161. doi:10.1186/1471-2180-13-161

Edwards, K.J., Bond, P.L., Gihring, T.M., Banfield, J.F., 2000. An Archaeal Iron-Oxidizing Extreme Acidophile Important in Acid Mine Drainage. Science 287, 1796-1799. doi:10.1126/science.287.5459.1796

Filipkowska, A., Kowalewska, G., Pavoni, B., 2014. Organotin compounds in surface sediments of the Southern Baltic coastal zone: a study on the main factors for their accumulation and degradation. Environ. Sci. Pollut. Res. 21, 2077-2087. doi:10.1007/s11356-013-2115-x

Francis, C.A., Roberts, K.J., Beman, J.M., Santoro, A.E., Oakley, B.B., 2005. Ubiquity and diversity of ammonia-oxidizing archaea in water columns and sediments of the ocean. Proc. Natl. Acad. Sci. U. S. A. 102, 14683-14688. doi:10.1073/pnas.0506625102

Frank, K.L., Rogers, D.R., Olins, H.C., Vidoudez, C., Girguis, P.R., 2013. Characterizing the distribution and rates of microbial sulfate reduction at Middle Valley hydrothermal vents. ISME J. 7, 1391-1401. doi:10.1038/ismej.2013.17

Gadd, G.M., 2000. Microbial interactions with tributyltin compounds: detoxification, accumulation, and environmental fate. Sci. Total Environ., TBT Costs and Benefits- A 258, 119-127. doi:10.1016/S0048-9697(00)00512-X

Gao, Y., de Brauwere, A., Elskens, M., Croes, K., Baeyens, W., Leermakers, M., 2013. Evolution of trace metal and organic pollutant concentrations in the Scheldt River Basin and the Belgian Coastal Zone over the last three decades. J. Mar. Syst. 128, 52-61. doi:10.1016/j.jmarsys.2012.04.002 
Gauthier, M., Lafay, B., Christen, R., Fernandez, L., Acquaviva, M., Bonin, P., Bertrand, J., 1992. Marinobacter-Hydrocarbonoclasticus Gen-Nov, Sp-Nov, a New, Extremely Halotolerant, Hydrocarbon-Degrading Marine Bacterium. Int. J. Syst. Bacteriol. 42, 568-576.

Gendron, A., Silverberg, N., Sundby, B., Lebel, J., 1986. Early diagenesis of cadmium and cobalt in sediments of the Laurentian Trough. Geochim. Cosmochim. Acta 50, 741747. doi:10.1016/0016-7037(86)90350-9

Gillan, D.C., Danis, B., Pernet, P., Joly, G., Dubois, P., 2005. Structure of SedimentAssociated Microbial Communities along a Heavy-Metal Contamination Gradient in the Marine Environment. Appl. Environ. Microbiol. 71, 679-690. doi:10.1128/AEM.71.2.679-690.2005

Gillan, D.C., Roosa, S., Kunath, B., Billon, G., Wattiez, R., 2014. The long-term adaptation of bacterial communities in metal-contaminated sediments: a metaproteogenomic study. Environ. Microbiol. doi:10.1111/1462-2920.12627

Guazzaroni, M.-E., Herbst, F.-A., Lores, I., Tamames, J., Isabel Pelaez, A., Lopez-Cortes, N., Alcaide, M., Del Pozo, M.V., Maria Vieites, J., von Bergen, M., Gallego, J.L.R., Bargiela, R., Lopez-Lopez, A., Pieper, D.H., Rossello-Mora, R., Sanchez, J., Seifert, J., Ferrer, M., 2013. Metaproteogenomic insights beyond bacterial response to naphthalene exposure and bio-stimulation. Isme J. 7, 122-136. doi:10.1038/ismej.2012.82

Hilton, J., Davison, W., Ochsenbein, U., 1985. A mathematical model for analysis of sediment core data: Implications for enrichment factor calculations and trace-metal transport mechanisms. Chem. Geol. 48, 281-291. doi:10.1016/0009-2541(85)900531

Jean, N., Dumont, E., Durrieu, G., Balliau, T., Jamet, J.-L., Personnic, S., Garnier, C., 2012. Protein expression from zooplankton communities in a metal contaminated. Mar. Environ. Res. 80, 12-26. doi:10.1016/j.marenvres.2012.06.004

Johnston, E.L., Roberts, D.A., 2009. Contaminants reduce the richness and evenness of marine communities: A review and meta-analysis. Environ. Pollut. 157, 1745-1752. doi:10.1016/j.envpol.2009.02.017

Jørgensen, B.B., 2000. Bacteria and Marine Biogeochemistry, in: Schulz, P.D.H.D., Zabel, D.M. (Eds.), Marine Geochemistry. Springer Berlin Heidelberg, pp. 173-207.

Kostka, J.E., Prakash, O., Overholt, W.A., Green, S.J., Freyer, G., Canion, A., Delgardio, J., Norton, N., Hazen, T.C., Huettel, M., 2011. Hydrocarbon-Degrading Bacteria and the Bacterial Community Response in Gulf of Mexico Beach Sands Impacted by the Deepwater Horizon Oil Spill. Appl. Environ. Microbiol. 77, 7962-7974. doi:10.1128/AEM.05402-11

Larrose, A., Coynel, A., Schäfer, J., Blanc, G., Massé, L., Maneux, E., 2010. Assessing the current state of the Gironde Estuary by mapping priority contaminant distribution and risk potential in surface sediment. Appl. Geochem. 25, 1912-1923. doi:10.1016/j.apgeochem.2010.10.007

Legendre, P., Legendre, L., 1998. Numerical Ecology, Volume 24, (Developments in Environmental Modelling).

Levin, L.A., Ekau, W., Gooday, A.J., Jorissen, F., Middelburg, J.J., Naqvi, S.W.A., Neira, C., Rabalais, N.N., Zhang, J., 2009. Effects of natural and human-induced hypoxia on coastal benthos. Biogeosciences 6, 2063-2098. doi:10.5194/bg-6-2063-2009

Li, J., Li, F., Yu, S., Qin, S., Wang, G., 2013. Impacts of mariculture on the diversity of bacterial communities within intertidal sediments in the Northeast of China. Microb. Ecol. 66, 861-870. doi:10.1007/s00248-013-0272-6

Long, E.R., Field, L.J., MacDonald, D.D., 1998. Predicting toxicity in marine sediments with numerical sediment quality guidelines. Environ. Toxicol. Chem. 17, 714-727. doi:10.1002/etc.5620170428

Long, E.R., Macdonald, D.D., Smith, S.L., Calder, F.D., 1995. Incidence of adverse biological effects within ranges of chemical concentrations in marine and estuarine sediments. Environ. Manage. 19, 81-97. doi:10.1007/BF02472006 
Louati, H., Ben Said, O., Soltani, A., Got, P., Mahmoudi, E., Cravo-Laureau, C., duran, R., Aissa, P., Pringault, O., 2013. The roles of biological interactions and pollutant contamination in shaping microbial benthic community structure. Chemosphere 93, 2535-2546. doi:10.1016/j.chemosphere.2013.09.069

Nicolau, R., Lucas, Y., Merdy, P., Raynaud, M., 2012. Base flow and stormwater net fluxes of carbon and trace metals to the Mediterranean sea by an urbanized small river. Water Res. 46, 6625-6637. doi:10.1016/j.watres.2012.01.031

Nies, D.H., 1999. Microbial heavy-metal resistance. Appl. Microbiol. Biotechnol. 51, 730-750.

Ortega-Retuerta, E., Joux, F., Jeffrey, W.H., Ghiglione, J.F., 2013. Spatial variability of particle-attached and free-living bacterial diversity in surface waters from the Mackenzie River to the Beaufort Sea (Canadian Arctic). Biogeosciences 10, 27472759. doi:10.5194/bg-10-2747-2013

Oursel, B., Garnier, C., Durrieu, G., Mounier, S., Omanović, D., Lucas, Y., 2013. Dynamics and fates of trace metals chronically input in a Mediterranean coastal zone impacted by a large urban area. Mar. Pollut. Bull. 69, 137-149. doi:10.1016/j.marpolbul.2013.01.023

Oursel, B., Garnier, C., Zebracki, M., Durrieu, G., Pairaud, I., Omanović, D., Cossa, D., Lucas, Y., 2014. Flood inputs in a Mediterranean coastal zone impacted by a large urban area: Dynamic and fate of trace metals. Mar. Chem., Estuarine Biogeochemistry 167, 44-56. doi:10.1016/j.marchem.2014.08.005

Paissé, S., Coulon, F., Goñi-Urriza, M., Peperzak, L., McGenity, T.J., Duran, R., 2008. Structure of bacterial communities along a hydrocarbon contamination gradient in a coastal sediment. FEMS Microbiol. Ecol. 66, 295-305. doi:10.1111/j.15746941.2008.00589.x

Paisse, S., Duran, R., Coulon, F., Goñi-Urriza, M., 2011. Are alkane hydroxylase genes (alkB) relevant to assess petroleum bioremediation processes in chronically polluted coastal sediments? Appl. Microbiol. Biotechnol. 92, 835-844. doi:10.1007/s00253011-3381-5

Parks, J.M., Johs, A., Podar, M., Bridou, R., Hurt, R.A., Smith, S.D., Tomanicek, S.J., Qian, Y., Brown, S.D., Brandt, C.C., Palumbo, A.V., Smith, J.C., Wall, J.D., Elias, D.A., Liang, L., 2013. The Genetic Basis for Bacterial Mercury Methylation. Science 339, 1332-1335. doi:10.1126/science.1230667

Pougnet, F., Schäfer, J., Dutruch, L., Garnier, C., Tessier, E., Dang, D.H., Lanceleur, L., Mullot, J.-U., Lenoble, V., Blanc, G., 2014. Sources and historical record of tin and butyl-tin species in a Mediterranean bay (Toulon Bay, France). Environ. Sci. Pollut. Res. Int. 21, 6640-6651. doi:10.1007/s11356-014-2576-6

Quillet, L., Besaury, L., Popova, M., Paissé, S., Deloffre, J., Ouddane, B., 2012. Abundance, diversity and activity of sulfate-reducing prokaryotes in heavy metal-contaminated sediment from a salt marsh in the Medway Estuary (UK). Mar. Biotechnol. N. Y. N 14, 363-381. doi:10.1007/s10126-011-9420-5

Ram, A.S.P., Palesse, S., Colombet, J., Thouvenot, A., Sime-Ngando, T., 2014. The relative importance of viral lysis and nanoflagellate grazing for prokaryote mortality in temperate lakes. Freshw. Biol. 59, 300-311. doi:10.1111/fwb.12265

Raskin, L., Stromley, J.M., Rittmann, B.E., Stahl, D.A., 1994. Group-specific 16S rRNA hybridization probes to describe natural communities of methanogens. Appl. Environ. Microbiol. 60, 1232-1240.

Rasmussen, L.D., Sorensen, S.J., 2001. Effects of mercury contamination on the culturable heterotrophic, functional and genetic diversity of the bacterial community in soil. Fems Microbiol. Ecol. 36, 1-9. doi:10.1016/S0168-6496(01)00111-8

Rensing, C., Fan, B., Sharma, R., Mitra, B., Rosen, B.P., 2000. CopA: An Escherichia coli $\mathrm{Cu}(\mathrm{I})$-translocating P-type ATPase. Proc. Natl. Acad. Sci. U. S. A. 97, 652-656.

RStudio Team, 2015. RStudio: Integrated Development for R. RStudio Inc Boston MA URL Httpwww RStudio Comide.

Salcher, M.M., 2013. Same same but different: ecological niche partitioning of planktonic freshwater prokaryotes. J. Limnol. 73. 
Sauret, C., Tedetti, M., Guigue, C., Dumas, C., Lami, R., Pujo-Pay, M., Conan, P., Goutx, M., Ghiglione, J.-F., 2015. Influence of PAHs among other coastal environmental variables on total and $\mathrm{PAH}-$ degrading bacterial communities. Environ. Sci. Pollut. Res. Int. doi:10.1007/s11356-015-4768-0

Scott, N.M., Hess, M., Bouskill, N.J., Mason, O.U., Jansson, J.K., Gilbert, J.A., 2014. The microbial nitrogen cycling potential is impacted by polyaromatic hydrocarbon pollution of marine sediments. Aquat. Microbiol. 5, 108. doi:10.3389/fmicb.2014.00108

Sklar, F.H., Browder, J.A., 1998. Coastal environmental impacts brought about by alterations to freshwater flow in the Gulf of Mexico. Environ. Manage. 22, 547-562. doi:10.1007/s002679900127

Stahl D, Amann R, n.d. Development and application of nucleic acid probes, in: Nucleic Acid Techniques in Bacterial Systematics. John Wiley \& Sons, Chichester, England, pp. 205-248.

Stevenson, B.A., Hunter, D.W.F., Rhodes, P.L., 2014. Temporal and seasonal change in microbial community structure of an undisturbed, disturbed, and carbon-amended pasture soil. Soil Biol. Biochem. 75, 175-185. doi:10.1016/j.soilbio.2014.04.010

Sun, M.Y., Dafforn, K.A., Brown, M.V., Johnston, E.L., 2012. Bacterial communities are sensitive indicators of contaminant stress. Mar. Pollut. Bull. 64, 1029-1038. doi:10.1016/j.marpolbul.2012.01.035

Sutherland, R.A., 2000. Bed sediment-associated trace metals in an urban stream, Oahu, Hawaii. Environ. Geol. 39, 611-627. doi:10.1007/s002540050473

Tessier, E., Garnier, C., Mullot, J.-U., Lenoble, V., Arnaud, M., Raynaud, M., Mounier, S., 2011. Study of the spatial and historical distribution of sediment inorganic contamination in the Toulon bay (France). Mar. Pollut. Bull. 62, 2075-2086. doi:10.1016/j.marpolbul.2011.07.022

Troussellier, M., Schafer, H., Batailler, N., Bernard, L., Courties, C., Lebaron, P., Muyzer, G., Servais, P., Vives-Rego, J., 2002. Bacterial activity and genetic richness along an estuarine gradient (Rhone River plume, France). Aquat. Microb. Ecol. 28, 13-24. doi:10.3354/ame028013

Van Wambeke, F., Ghiglione, J.-F., Nedoma, J., Mével, G., Raimbault, P., 2009. Bottom up effects on bacterioplankton growth and composition during summer-autumn transition in the open NW Mediterranean Sea. Biogeosciences 6, 705-720. doi:10.5194/bg-6705-2009

Waterkeyn, A., Grillas, P., Vanschoenwinkel, B., Brendonck, L., 2008. Invertebrate community patterns in Mediterranean temporary wetlands along hydroperiod and salinity gradients. Freshw. Biol. 53, 1808-1822. doi:10.1111/j.13652427.2008.02005.x

Winemiller, K., Leslie, M., 1992. Fish Assemblages Across a Complex, Tropical Fresh-Water Marine Ecotone. Environ. Biol. Fishes 34, 29-50. doi:10.1007/BF00004783

Wolska, L., Mechlińska, A., Rogowska, J., Namieśnik, J., 2014. Polychlorinated biphenyls (PCBs) in bottom sediments: Identification of sources. Chemosphere 111, 151-156. doi:10.1016/j.chemosphere.2014.03.025 
Click here to download Table: table 1.docx

Table 1. Chemical characterization of the Toulon bay surface sediments.

\begin{tabular}{|c|c|c|c|c|c|c|c|c|c|c|c|c|c|c|}
\hline $\begin{array}{l}\text { Variable groups } \\
\text { (unit) }\end{array}$ & $\begin{array}{c}\text { Chemical } \\
\text { parameters }\end{array}$ & $N$ & $\begin{array}{l}\text { Content range } \\
\text { (median) }\end{array}$ & $\begin{array}{l}\text { SWA } \\
\text { content }\end{array}$ & $\begin{array}{l}\text { EF range } \\
\text { (median) }\end{array}$ & \multicolumn{4}{|c|}{ Surface (\%) per EF level } & \multicolumn{2}{|c|}{$\begin{array}{c}\text { ERL } \text { ERM } \\
\left(\mu \mathrm{g} \mathrm{g}^{-1}\right)\end{array}$} & Content < ERL & $\begin{array}{l}\text { Surface (\%) per ER leve } \\
\text { ERL }<\text { content }<\text { ERM }\end{array}$ & Content $>$ ERM \\
\hline $\begin{array}{l}\text { Marine } \\
\left(\mu g . g^{-1}\right)\end{array}$ & $\mathrm{Ca}$ & 54 & 84000 - $320000(140000)$ & 191000 & - & - & - & - & - & - & - & - & - & - \\
\hline Terrigeneous & $\mathrm{Al}$ & 54 & $4700-57000(29000)$ & 22000 & - & - & - & - & - & - & - & - & - & - \\
\hline$\left(\mu \mathrm{g} \cdot \mathrm{g}^{-1}\right)$ & $\mathrm{Fe}$ & 54 & $5400-35000(19000)$ & 16000 & - & - & - & - & - & - & - & - & - & - \\
\hline Natural & Co & 54 & $1.9-10(6.2)$ & 5.56 & $1-6.5(1.6)$ & 15.8 & 83.7 & 0.5 & 0.0 & - & - & - & - & - \\
\hline$\left(\mu \mathrm{g} \cdot \mathrm{g}^{-1}\right)$ & $\mathrm{Ni}$ & 54 & $5.1-40(22)$ & 17.7 & $1-1.9(1.3)$ & 91.4 & 8.6 & 0.0 & 0.0 & 20.9 & 51.6 & 65.0 & 35.0 & 0.0 \\
\hline \multirow{4}{*}{$\begin{array}{l}\text { Mixed } \\
\left(\mu g \cdot g^{-1}\right)\end{array}$} & As & 54 & $6.2-80(21)$ & 19.8 & $0.7-21(2.1)$ & 2.2 & 92.1 & 5.7 & 0.0 & 8.2 & 70 & 1.3 & 98.5 & 0.1 \\
\hline & $\mathrm{Cr}$ & 54 & $12-95(38)$ & 31.9 & $1.5-3.9(2)$ & 0.9 & 99.1 & 0.0 & 0.0 & 81 & 370 & 99.5 & 0.5 & 0.0 \\
\hline & $\mathrm{Mn}$ & 54 & $99-930(150)$ & 185 & - & - & - & - & - & - & - & - & - & - \\
\hline & $S$ & 54 & $2900-17000(6100)$ & 5470 & - & - & - & - & - & - & - & - & - & - \\
\hline \multirow{12}{*}{$\begin{array}{c}\text { Inorganic } \\
\text { contaminants } \\
\left(\mu \mathrm{g} \cdot \mathrm{g}^{-1}\right)\end{array}$} & $\mathrm{Ag}$ & 54 & $0.061-2.8(0.32)$ & 0.31 & $0.9-22(3.4)$ & 1.6 & 87.4 & 11.0 & 0.1 & 1.0 & 3.7 & 94.4 & 5.7 & 0.0 \\
\hline & $\mathrm{Ba}$ & 54 & $30-480(150)$ & 134 & $1.7-5.2(2.6)$ & 0.0 & 99.7 & 0.3 & 0.0 & - & - & - & - & - \\
\hline & $\mathrm{Bi}$ & 54 & $0.17-4.6(0.82)$ & 0.63 & $1.5-25(5.5)$ & 0.0 & 48.4 & 51.5 & 0.1 & - & - & - & - & - \\
\hline & $\mathrm{Cd}$ & 54 & $0.07-1.7(0.21)$ & 0.202 & $1.2-14(2.3)$ & 2.3 & 88.2 & 9.6 & 0.0 & 1.2 & 9.6 & 99.6 & 0.4 & 0.0 \\
\hline & $\mathrm{Cu}$ & 54 & $5.6-730(65)$ & 60.5 & $1-54(6.4)$ & 1.3 & 50.3 & 46.6 & 1.7 & 34 & 270 & 43.3 & 54.8 & 1.9 \\
\hline & $\mathrm{Hg}$ & 54 & $0.03-27(1.6)$ & 1.54 & $1.7-1200(77)$ & 0.0 & 0.7 & 20.3 & 79.1 & 0.15 & 0.71 & 11.6 & 40.7 & 47.8 \\
\hline & $P$ & 54 & $290-930(540)$ & 474 & $2.1-16(2.9)$ & 0.0 & 80.8 & 19.2 & 0.0 & - & - & - & - & - \\
\hline & $\mathrm{Pb}$ & 54 & $15-470(99)$ & 77 & $1.6-38(9.6)$ & 0.0 & 9.8 & 89.6 & 0.6 & 46.7 & 218 & 33.9 & 64.6 & 1.5 \\
\hline & $\mathrm{Sb}$ & 54 & $0.18-5.5(0.62)$ & 0.786 & $1.8-44(4)$ & 0.0 & 47.9 & 50.1 & 2.1 & - & - & - & - & - \\
\hline & Sn & 54 & $0.94-120(10)$ & 12.9 & $1.3-50(5.2)$ & 2.6 & 37.7 & 55.8 & 4.0 & - & - & - & - & - \\
\hline & $\mathrm{Ti}$ & 54 & $91-640(370)$ & 320 & $1.1-3.4(1.7)$ & 21.4 & 78.6 & 0.0 & 0.0 & - & - & - & - & - \\
\hline & $\mathrm{Zn}$ & 54 & $27-1500(150)$ & 136 & $1.7-31(4.5)$ & 0.0 & 77.1 & 22.6 & 0.4 & 150 & 410 & 68.6 & 28.4 & 3.1 \\
\hline Organometallic & $\mathrm{MMHg}$ & 54 & $0.18-15(2.5)$ & 1.99 & - & - & - & - & - & - & - & - & - & - \\
\hline contaminants & TBT & 29 & $0.2-2700(24)$ & - & - & - & - & - & - & - & - & - & - & - \\
\hline$\left(\mathrm{ng} \cdot \mathrm{g}^{-1}\right)$ & $\Sigma \mathrm{BT}$ & 29 & $0.86-4500(140)$ & - & - & - & - & - & - & - & - & - & - & - \\
\hline Organic & CB-153 & 25 & $0.013-0.42(0.05)$ & - & - & - & - & - & - & - & - & - & - & - \\
\hline contaminants & $\Sigma \mathrm{CB}$ & 25 & $0.018-1.6(0.11)$ & - & - & - & - & - & - & 0.023 & 0.18 & - & - & - \\
\hline$\left(\mu g \cdot g^{-1}\right)$ & fluoranthene & 25 & $0.34-6.2(2.1)$ & - & - & - & - & - & - & 0.60 & 5.1 & - & - & - \\
\hline
\end{tabular}




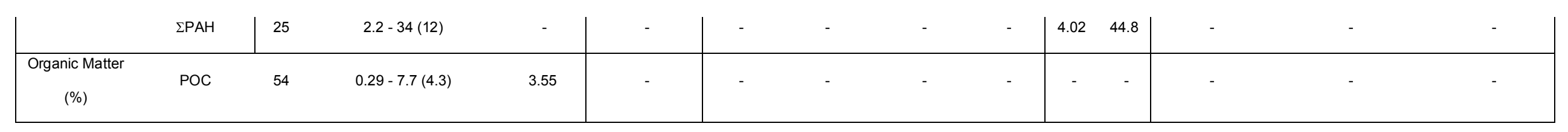


Table 2. Spearman's correlation tests between archaeal or bacterial T-RF richness and chemical variables. Numbers represent $\rho$ values of statistically significant correlations. $n=38$ for most of the correlation analyses, except for BTs and organic compounds for which $n=24$ and 19 , respectively. ns: non significant. $*$ : $p<0.05, * * p<0.01, * * * p<0.001$

\begin{tabular}{|c|c|c|c|}
\hline Variable groups & Chemical parameters & Archaea & Bacteria \\
\hline Marine & $\mathrm{Ca}$ & ns & $-0.38^{*}$ \\
\hline Terrigeneous & $\begin{array}{l}A l \\
F e\end{array}$ & $\begin{array}{l}0.35^{\star} \\
0.36^{\star}\end{array}$ & $\begin{array}{l}0.54^{\star \star *} \\
0.48^{\star *}\end{array}$ \\
\hline Natural & $\begin{array}{l}\mathrm{Co} \\
\mathrm{Ni}\end{array}$ & $\begin{array}{l}\text { ns } \\
\text { ns }\end{array}$ & $\begin{array}{c}\text { ns } \\
0.35^{*}\end{array}$ \\
\hline Mixed & $\begin{array}{l}\text { As } \\
\mathrm{Cr} \\
\mathrm{Mn} \\
\mathrm{S}\end{array}$ & $\begin{array}{c}\text { ns } \\
0.33^{*} \\
\text { ns } \\
\text { ns }\end{array}$ & $\begin{array}{c}0.38^{*} \\
0.54^{\star \star *} \\
\text { ns } \\
0.57^{\star \star \star}\end{array}$ \\
\hline $\begin{array}{c}\text { Inorganic } \\
\text { contaminants } \\
\text { (EF) }\end{array}$ & $\begin{array}{l}\mathrm{Ag} \\
\mathrm{Ba} \\
\mathrm{Bi} \\
\mathrm{Cd} \\
\mathrm{Cu} \\
\mathrm{Hg} \\
\mathrm{P} \\
\mathrm{Pb} \\
\mathrm{Sb}\end{array}$ & $\begin{array}{c}0.41^{*} \\
\mathrm{~ns} \\
0.50^{\star *} \\
\mathrm{~ns} \\
0.39^{*} \\
0.41^{*} \\
\mathrm{~ns} \\
0.45^{\star *} \\
\mathrm{~ns}\end{array}$ & $\begin{array}{c}0.70^{\star * *} \\
\mathrm{~ns} \\
\mathrm{~ns} \\
\mathrm{~ns} \\
0.55^{\star * *} \\
0.51^{\star *} \\
\mathrm{~ns} \\
\mathrm{~ns} \\
\mathrm{~ns}\end{array}$ \\
\hline
\end{tabular}




\begin{tabular}{|c|c|c|c|}
\hline & Sn & ns & ns \\
\hline & $\mathrm{Ti}$ & ns & ns \\
\hline & $Z n$ & $0.44^{* *}$ & $0.48^{* *}$ \\
\hline \multirow{3}{*}{$\begin{array}{l}\text { Organometallic } \\
\text { contaminants }\end{array}$} & $\mathrm{MMHg}$ & $0.38^{*}$ & $0.59^{* * *}$ \\
\hline & TBT & $0.06^{*}$ & $0.73^{\star * *}$ \\
\hline & $\Sigma B T$ & $0.47^{*}$ & $0.73^{* * *}$ \\
\hline \multirow{4}{*}{$\begin{array}{c}\text { Organic } \\
\text { contaminants }\end{array}$} & Fluoranthene & ns & ns \\
\hline & $\Sigma P A H$ & ns & ns \\
\hline & $C B-153$ & ns & $0.47^{*}$ \\
\hline & $\Sigma P C B$ & ns & $0.47^{*}$ \\
\hline Organic matter & $P O C$ & ns & ns \\
\hline Sediment & Metal based m-ERM-Q & $0.42^{* *}$ & $0.55^{\star \star *}$ \\
\hline potential toxicity & $m-E R M-Q$ with $P A H s$ & $0.50^{*}$ & ns \\
\hline
\end{tabular}




\section{FIGURE CAPTIONS}

Figure 1. Sampling stations and main anthropogenic activities in Toulon bay. Dots represents the specific sites where organic contaminants were quantified, small grey squares represent the sampling sites with butyl-tin species measurements and large open squares represent the sites from which samples were analyzed through T-RFLP.

Figure 2. Examples of benthic abiotic spatial gradients in the Toulon bay. $\boldsymbol{A}, \boldsymbol{B}, \boldsymbol{C}$ : contents of $A l, C d$ and $C B-153$, respectively. D: Gower similarity, the white arrows represent the reference sites. E: m-ERM-Q calculated with toxic metals' concentrations. Scales were drawn according to deciles of the respective datasets.

Figure 3. Spatial variations of prokaryotic richness and community structure in surface sediments of Toulon bay, calculated from t-RFLP data. $\boldsymbol{A}$ and $\boldsymbol{B}$ : bacterial and archaeal richnesses, respectively. C and D: Bray-Curtis similarities of T-RF structure within bacterial and archaeal communities, respectively. Arrows design the reference sites used for representing similarities.

Figure 4. PCoA of bacterial (A) and archaeal (B) communities using Bray-Curtis distances, calculated from normalized tRFLP data. LiB: Little Bay, LaB: Large Bay 


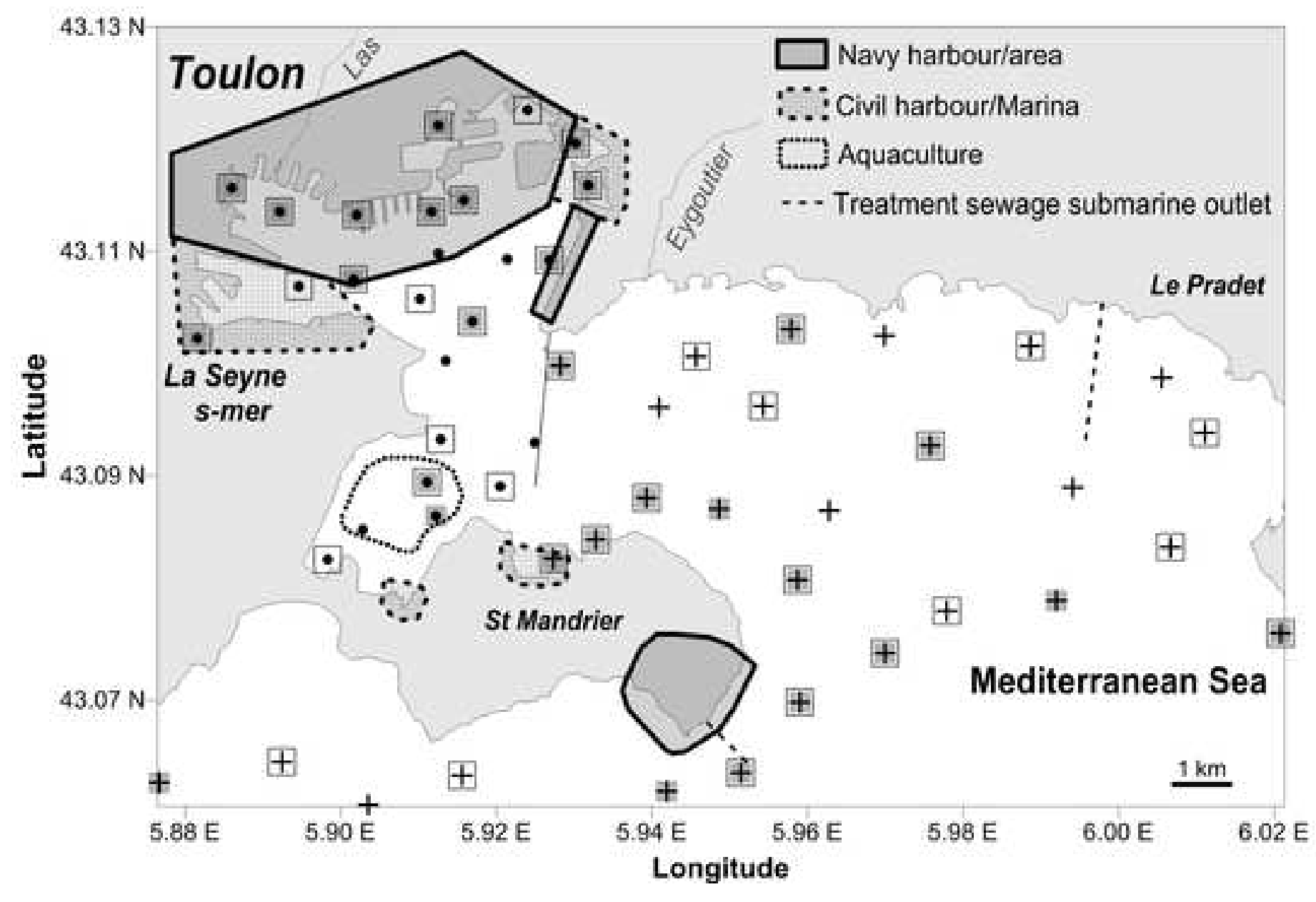


Click here to download high resolution image

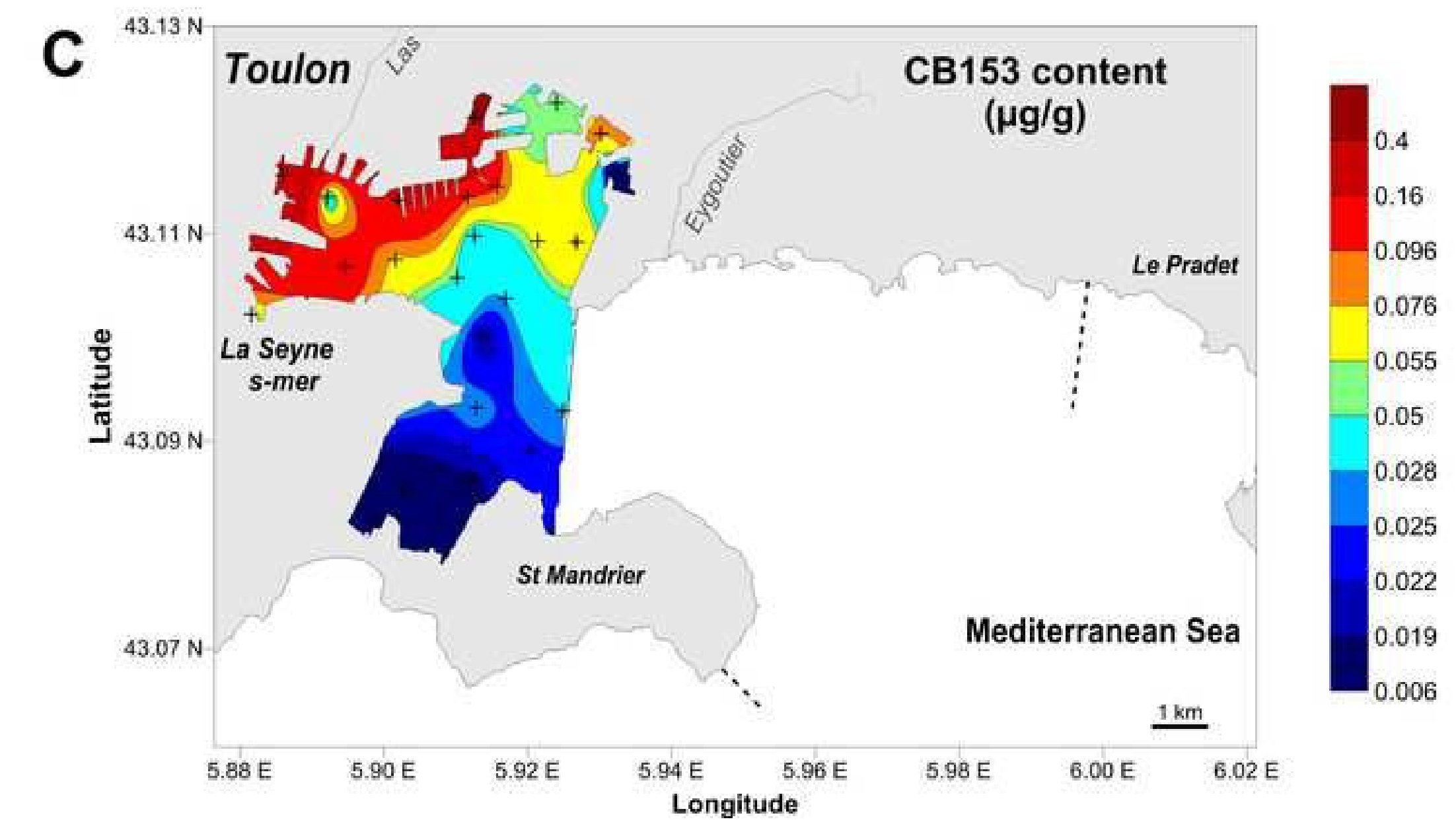




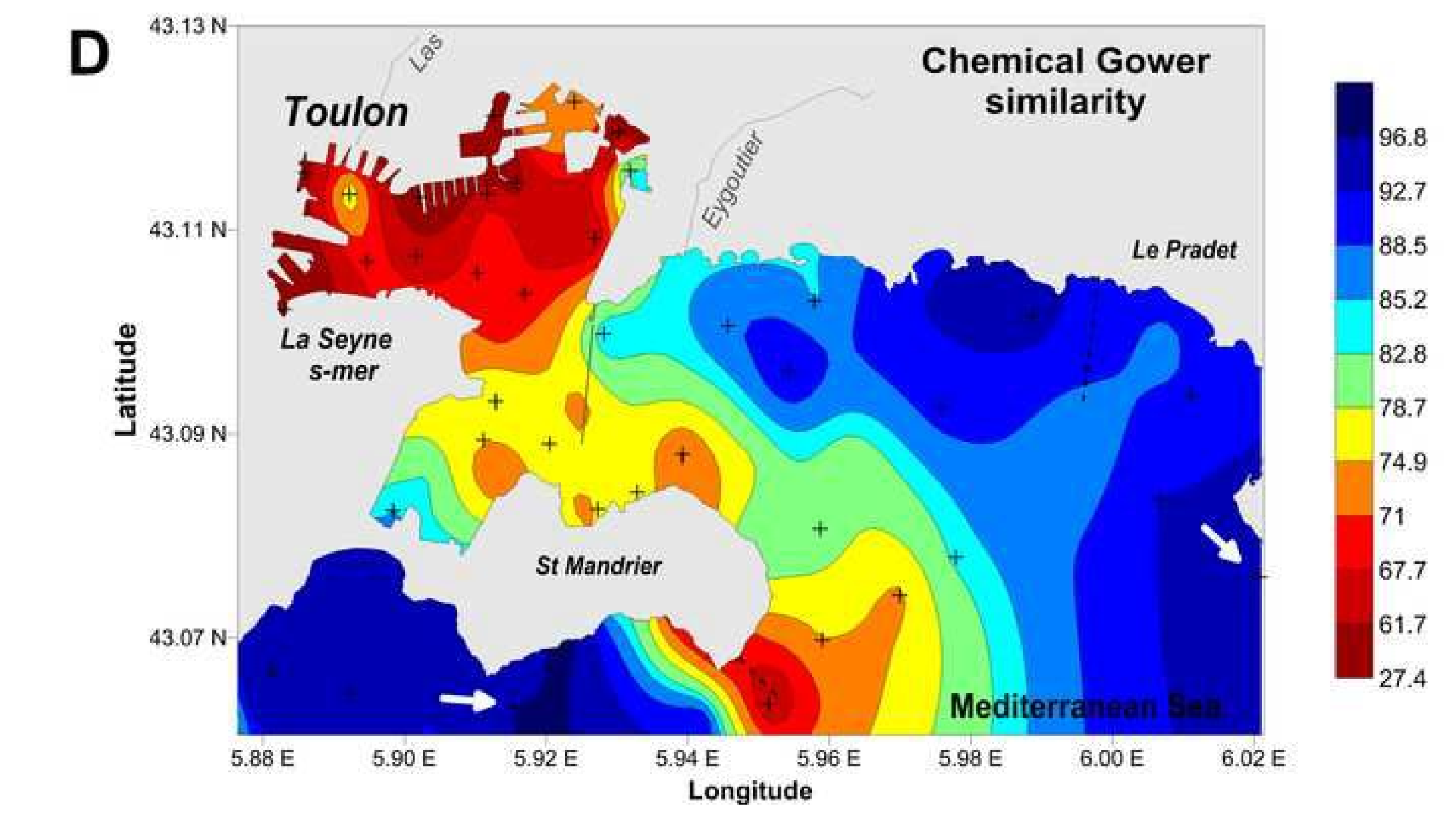

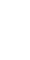




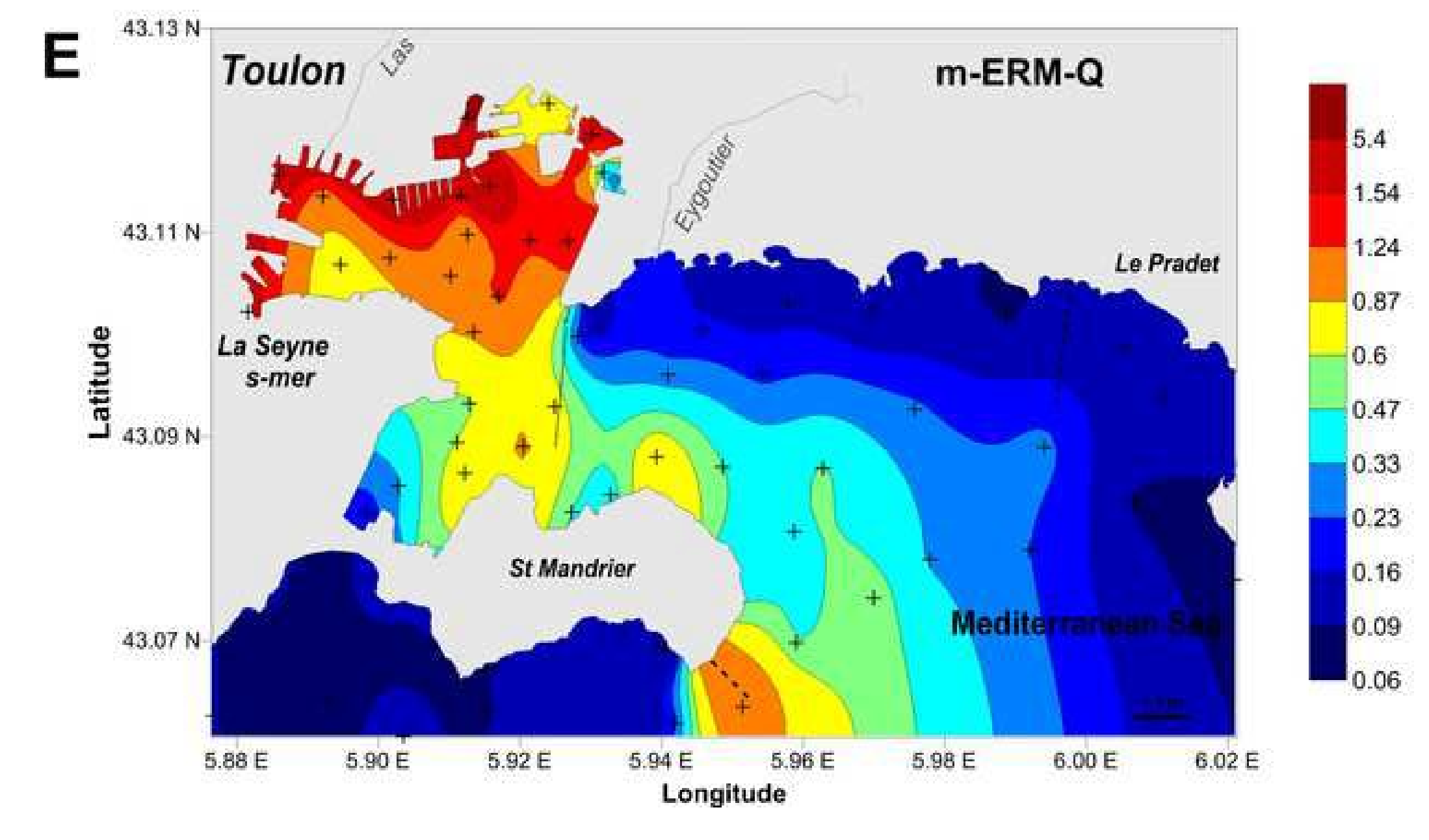




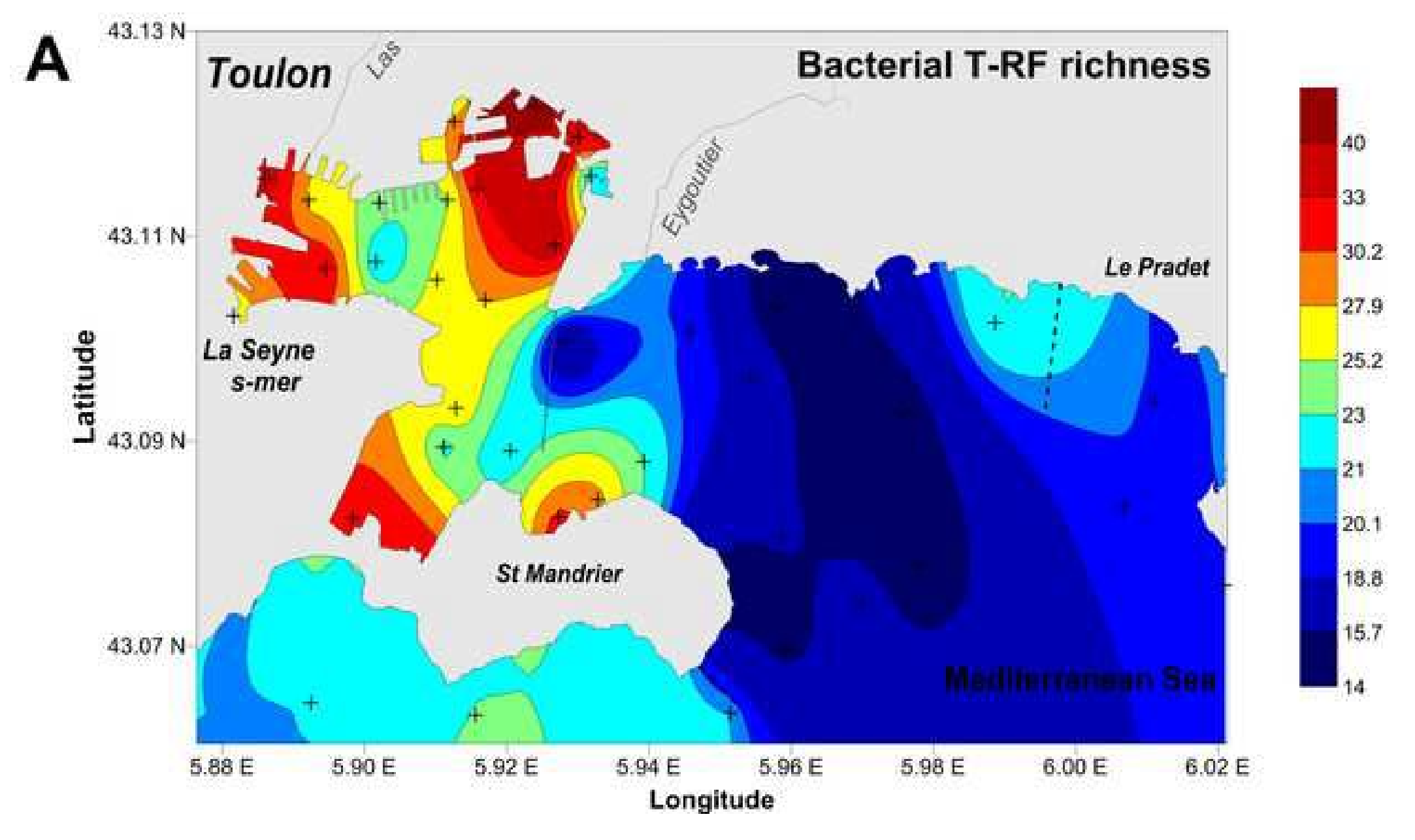

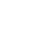

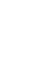




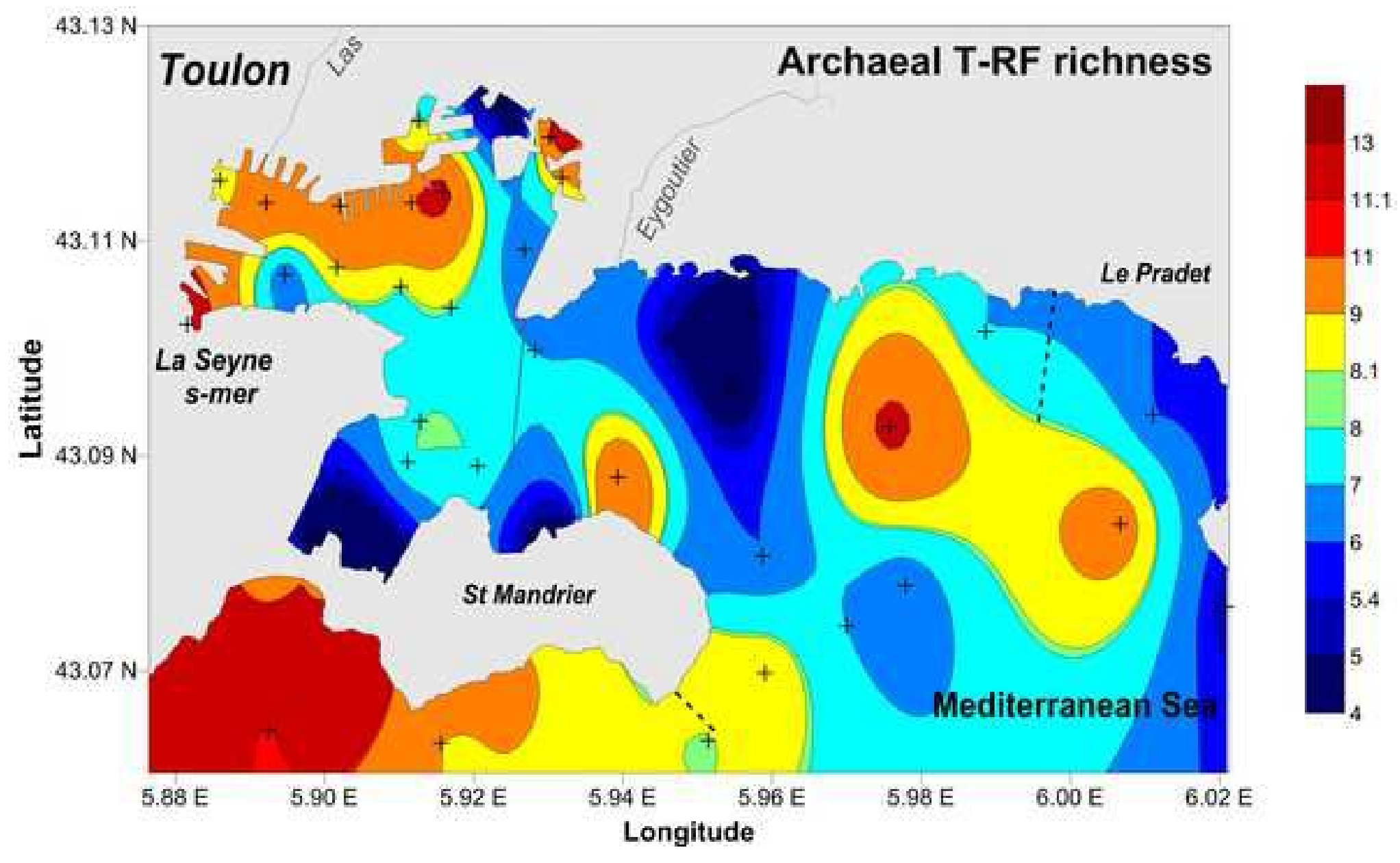

B 


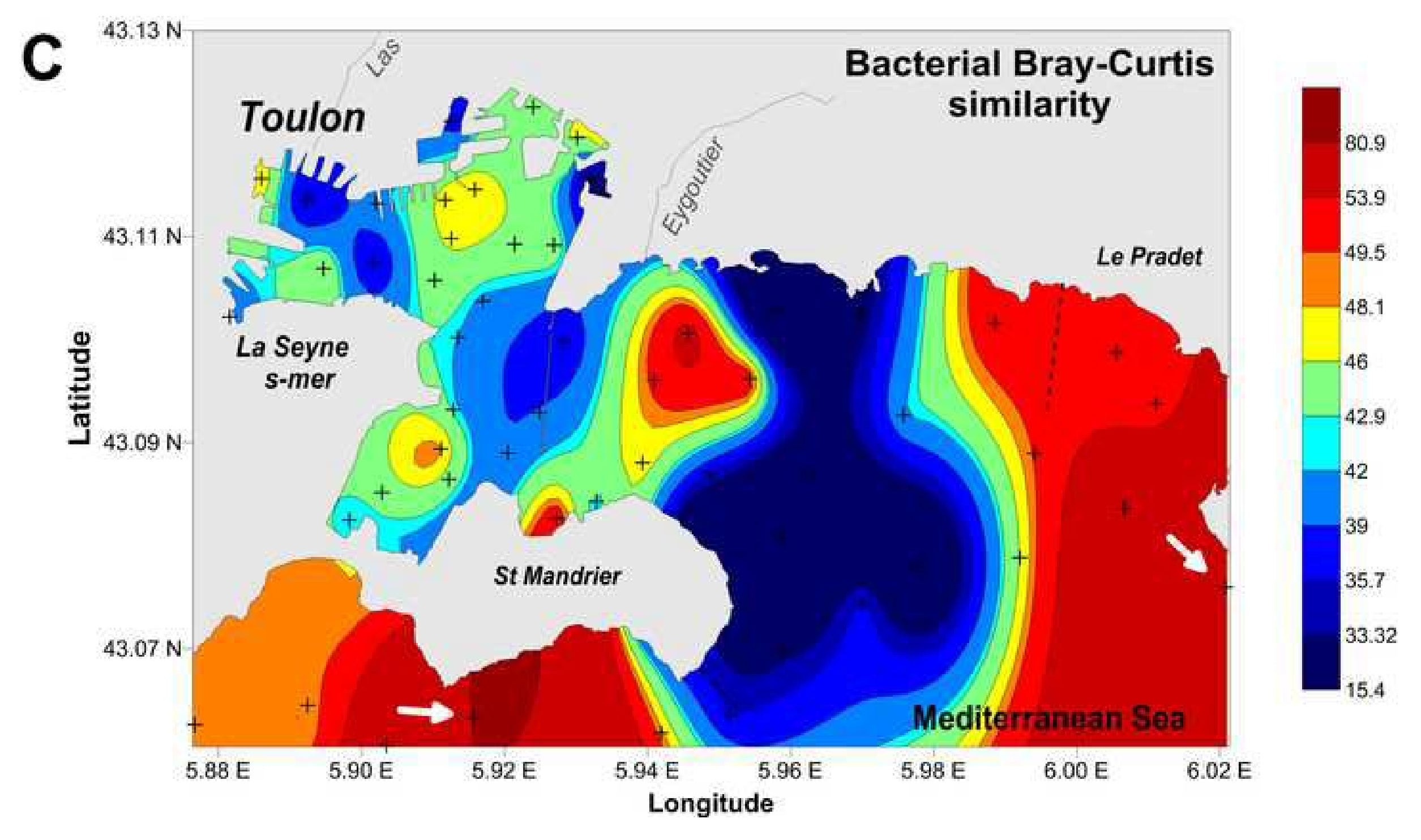




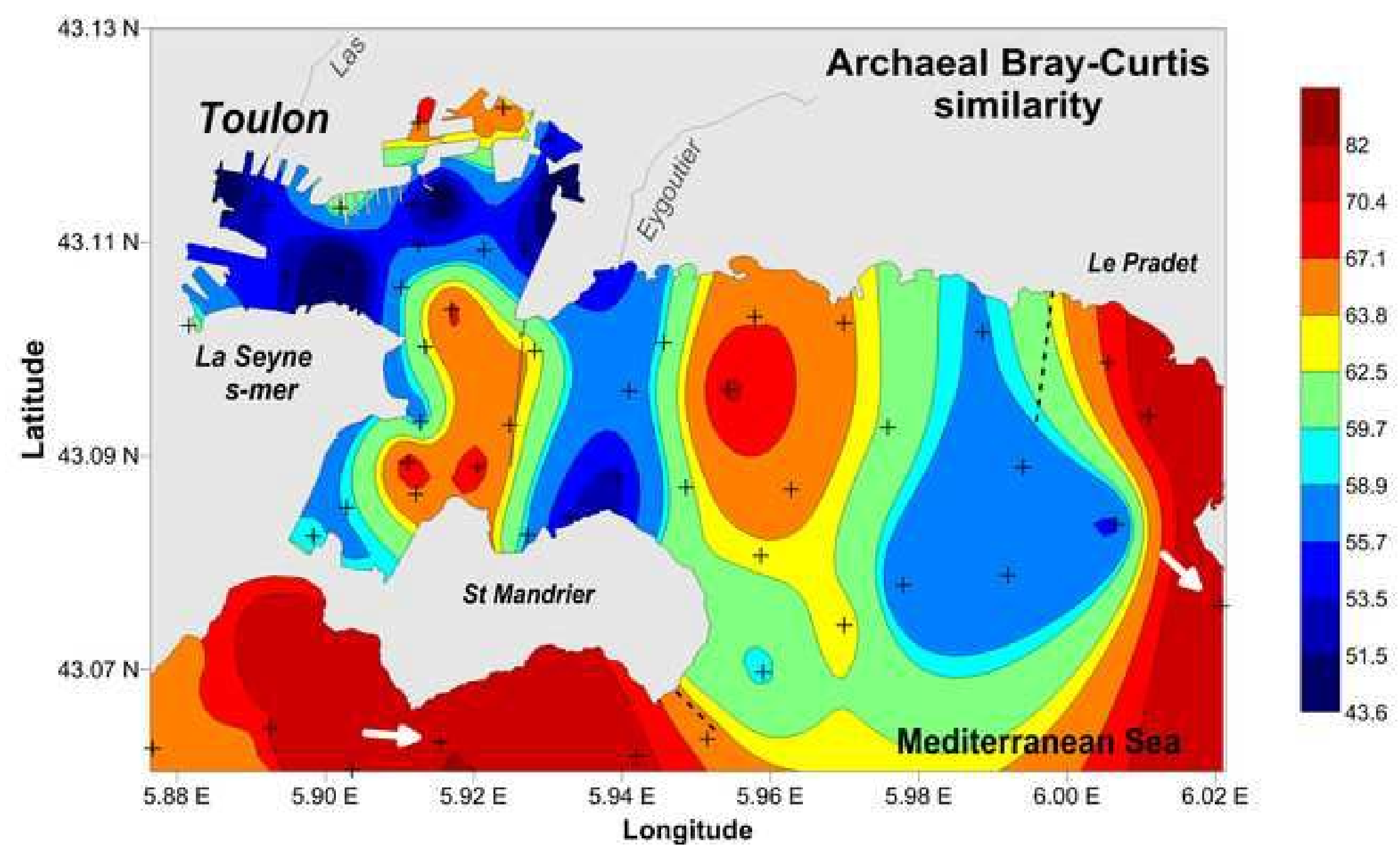

D 
Figure4A_online
Click here to download high resolution image

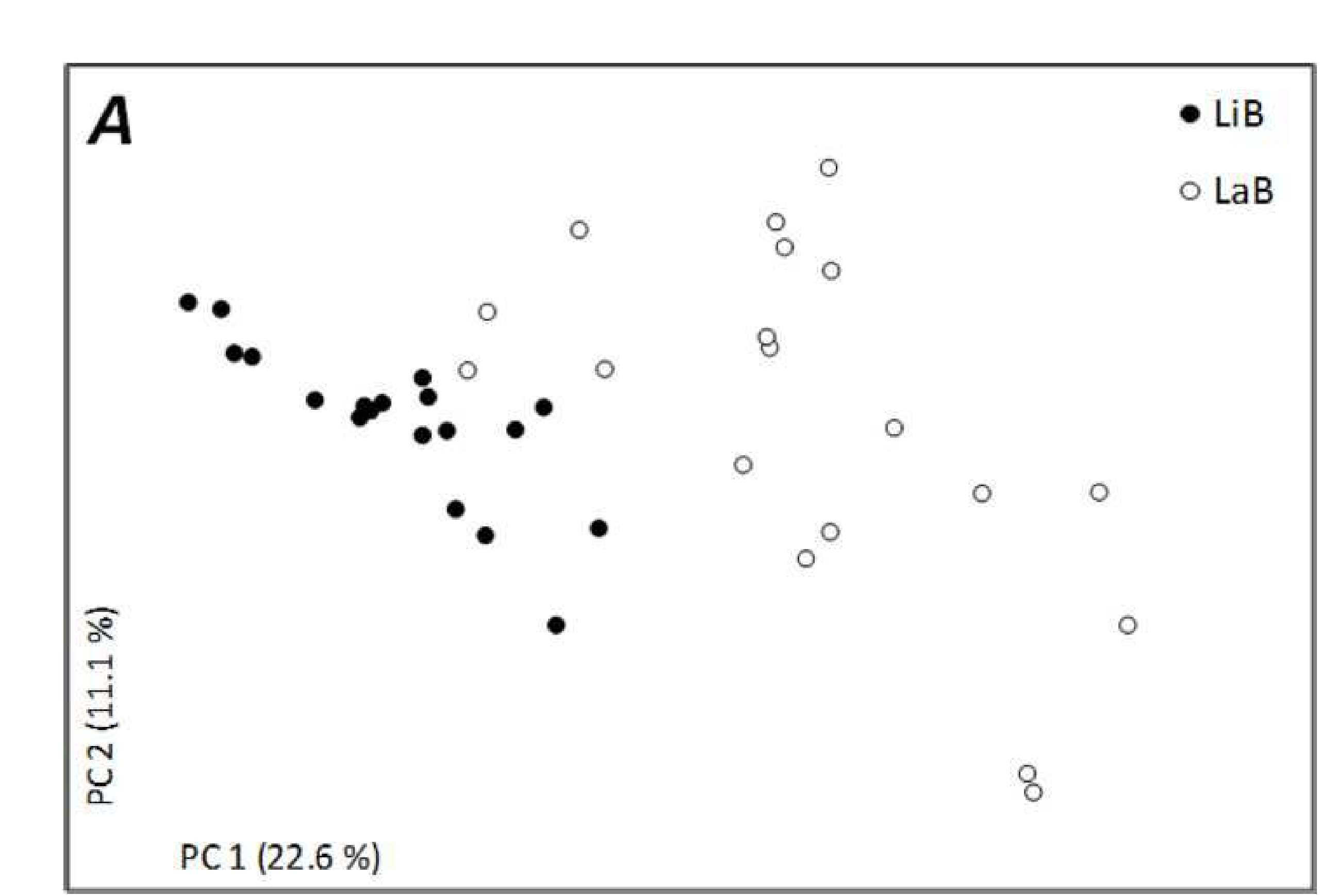

- LiB

- LaB

o

$0^{0}$

PC 1 (22.6\%) 


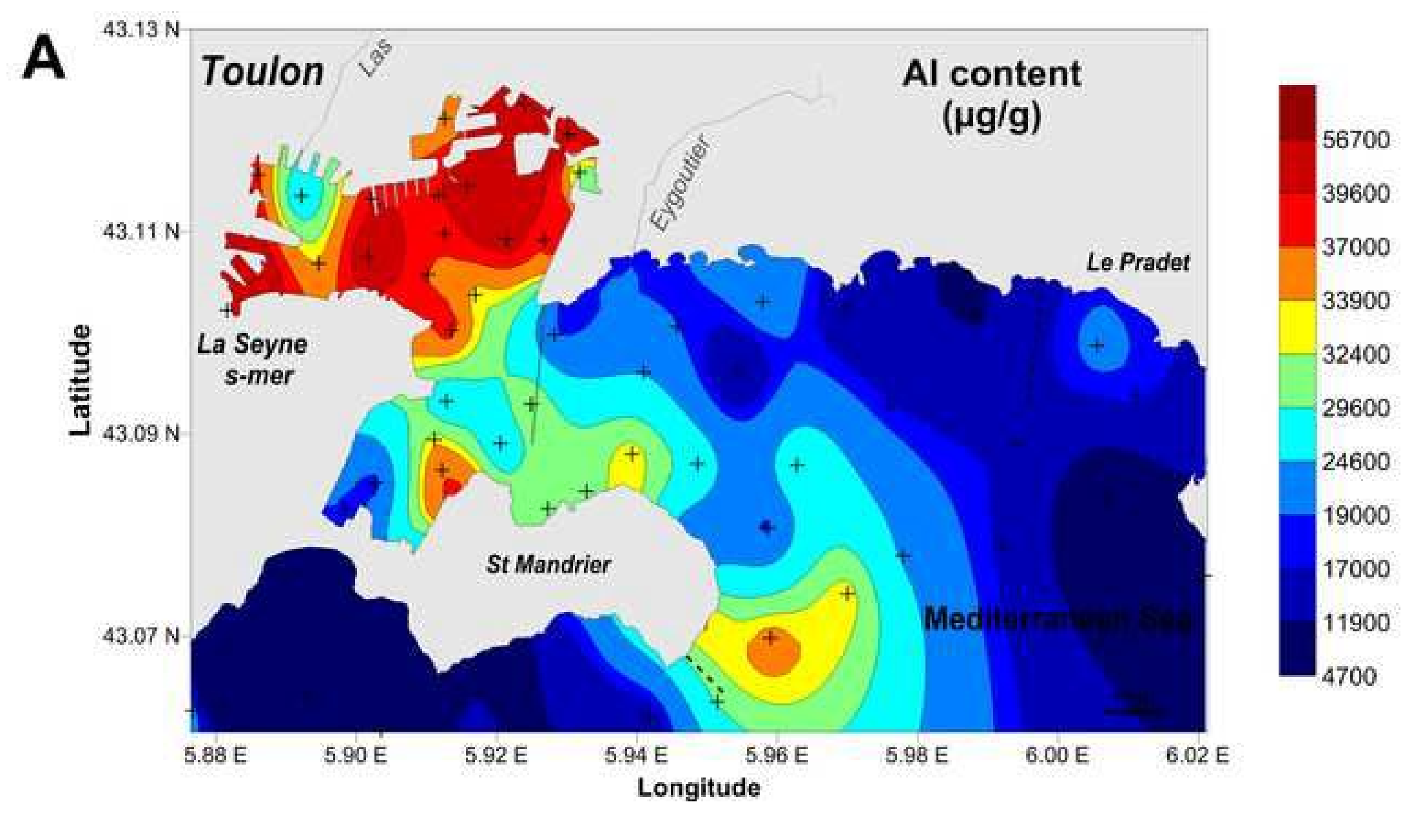




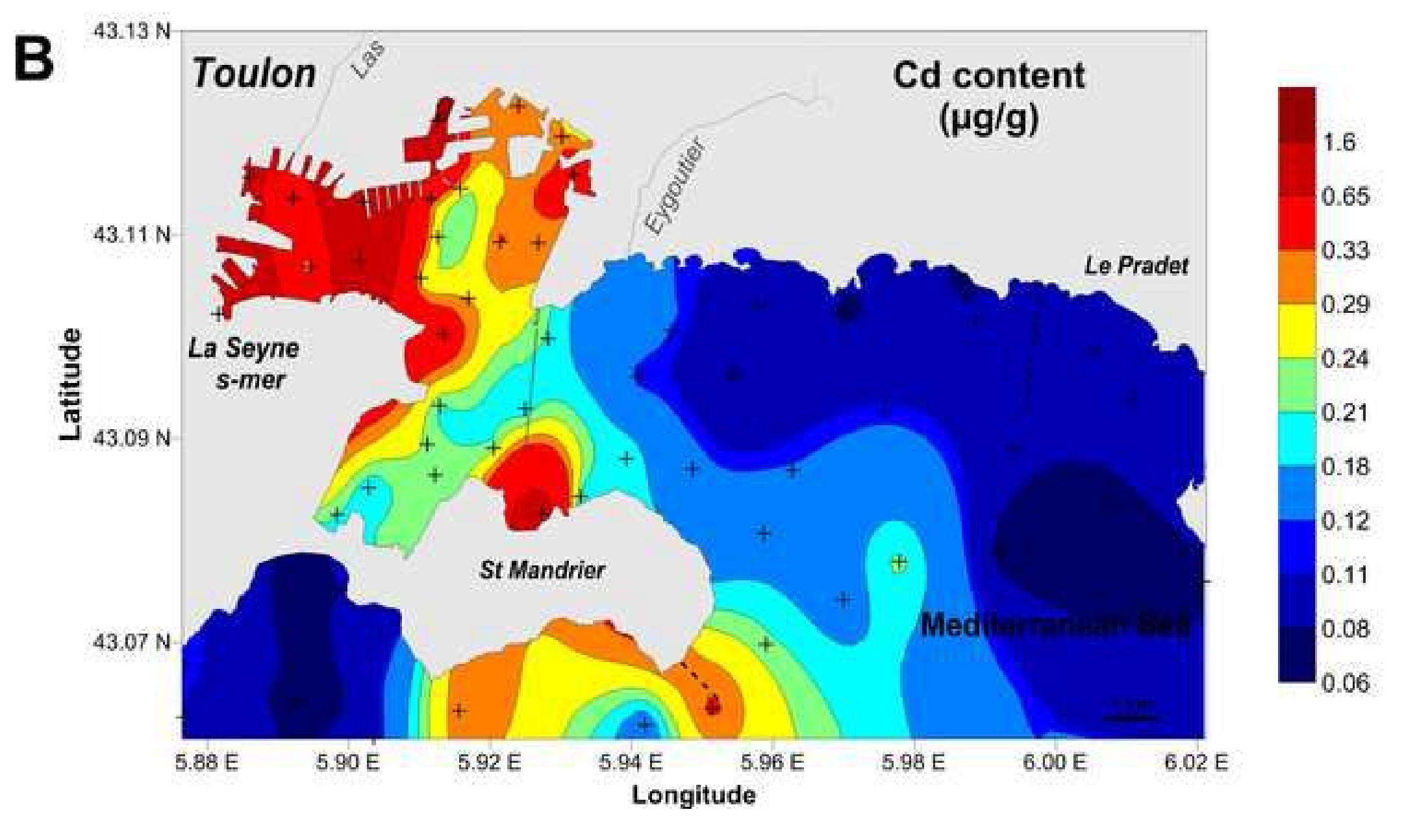

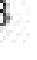
1 . 
